\title{
Quantifying the Effect of Supplementation with Algae and Its Extracts on Glycolipid Metabolism: A Meta-Analysis of Randomized Controlled Trials
}

\author{
Kun-xiang Ding ${ }^{1,2}$, Tian-lin Gao ${ }^{1,2}$, Rui Xu ${ }^{1,2}$, Jing Cai ${ }^{1,2}$, Hua-qi Zhang ${ }^{1,2}$, Yong-ye Sun ${ }^{1,2}$, \\ Feng Zhong ${ }^{1,2, *}$ and Ai-guo Ma ${ }^{1,2}$ \\ 1 School of Public Health, Qingdao University, Qingdao 266021, China; dkunxiang@163.com (K.-x.D.); \\ gaot1@qdu.edu.cn (T.-1.G.); xurui9510@163.com (R.X.); 15165231565@163.com (J.C.); \\ huaqi_erin@163.com (H.-q.Z.); yongye.sun@126.com (Y.-y.S.); magfood@126.com (A.-g.M.) \\ 2 Institute of nutrition and health, Qingdao University, Qingdao 266021, China \\ * Correspondence: zhfeng@qdu.edu.cn; Tel.: +86-186-6183-3099
}

Received: 11 April 2020; Accepted: 4 June 2020; Published: 8 June 2020

\begin{abstract}
Aims: The effect of algae and its extract supplementation on glycolipid metabolism has not been finalized. Therefore, the purpose of the meta-analyses was to assess the effects of its supplementation on glycolipid metabolism concentration. Methods: We have systematically searched PubMed, Web of Science, the Cochrane Library and Embase to identify randomized controlled trials (RCTs) that investigated the impact of algae and its extracts supplementation on glycolipid metabolism. Effect size analysis was performed using weighted mean difference (WMD) and $95 \%$ CI between the methods of the experiment group and the control group. Subgroup analyses were performed to explore the possible influences of study characteristics. Publication bias and sensitivity analysis were also performed. Results: A total of 27 RCTs ( 31 trials) with 1221 participants were finally selected for the meta-analysis. The algae and its extract intervention significantly decreased glycosylated hemoglobin (HbA1c, $\mathrm{WMD}=-0.18 \% ; 95 \% \mathrm{CI}:-0.27$ to $-0.10 ; p<0.001$ ), high-density lipoprotein cholesterol (HDL-C, $\mathrm{WMD}=-0.22 \mathrm{mmol} / \mathrm{L} ; 95 \% \mathrm{CI}:-0.38$ to $-0.06 ; p=0.008)$, and triglycerides $(\mathrm{TC}, \mathrm{WMD}=-0.31 \mathrm{mmol} / \mathrm{L}$; $95 \%$ CI: -0.37 to $-0.25 ; p<0.001$ ) levels and increased insulin (WMD $=6.05 \mathrm{pmol} / \mathrm{mL} ; 95 \% \mathrm{CI}$ : 4.01 to $8.09 ; p<0.001$ ) levels. It did not significantly change the blood glucose, homeostasis model assessment-insulin resistance index (HOMA-IR), 2-h post-meal blood glucose (2hPBG) and other lipid profiles. Subgroup analyses based on the duration of intervention and subjects demonstrated that the intervention of algae and its extracts for 10 weeks or fewer and more than 40 subjects decreased TC levels $(p<0.05)$. Moreover, the intervention reduced TC and 2hPBG concentrations for East Asians $(p<0.05)$. Conclusions: Our findings provided evidence that algae and its extract interventions were beneficial for the regulation of human glycolipid metabolism. More precise RCTs on subjects are recommended to further clarify the effect of algae, seaweed polysaccharide, seaweed polypeptide, algae polyphenol and its products intervention on glycolipid metabolism.
\end{abstract}

Keywords: algae; glycolipid metabolism; blood glucose; lipid profiles; meta-analyses

\section{Introduction}

In recent years, with the rapid development of the global economy and the increase of unhealthy lifestyles, diabetes and cardiovascular diseases have become the most common diseases with the highest mortality rates in the world [1,2]. According to the World Health Organization, more than 17.3 million people die of cardiovascular disease each year, and it is expected that the number of cardiovascular disease-related deaths will increase to more than 23.6 million by 2030 [3]. Atherosclerosis (AS) is the 
main pathological basis of cardiovascular diseases [4,5]. During the occurrence and development of AS, abnormal metabolism of neutral lipids, especially cholesterol and apolipoproteins, is the main factor leading to the occurrence and development of cardiovascular diseases [6-8]. Diabetes mellitus (DM) is a chronic disease, a condition caused either by insufficient insulin secretion or insulin resistance [9] characterized by hyperglycemia, and is widely prevalent worldwide and usually accompanied by impaired glucose tolerance (IGT), hypertension and hyperlipidemia [10]. In 2017, approximately 451 million adults worldwide had diabetes, and this number is expected to increase to 693 million by 2045 [11]. Abnormal glucose metabolism and lipid metabolism often occur in parallel. Therefore, blood glucose control and lipid control treatment should be carried out simultaneously.

Seaweed plays an important role in regulating chronic diseases because of its unique biologically active compounds, such as fucoidan, alginate, fucosterol, phlorotannins and phycocyanin, which are not found in terrestrial plant sources [12-14]. It can regulate intestinal health and reduce risk factors of diabetes, antiviral, anticancer, anticoagulation, etc. [15]. Dietary studies in Japan and South Korea showed that consumption of seaweed can reduce the incidence of chronic diseases such as cancer, hyperlipidemia and coronary heart disease $[16,17]$. The existing evidence shows that algae, especially spirulina, has antioxidant, anti-inflammatory, antitumor, antiviral, antibacterial and other health-promoting functions, and has a positive therapeutic effect on hyperlipidemia, obesity, cardiac vascular disease (CVD) and diabetes $[15,18-21]$. Polyphenols extracted from seaweed are thought to contribute to reducing the risk of cardiovascular disease and diabetes complications due to hyperglycemia, hyperlipidemia, oxidative damage and chronic inflammation, as well as metabolic abnormalities [22]. Recently, there have been many reports on the improvement of diabetes, obesity and hyperlipidemia by the bioactive ingredients in natural foods, especially seaweed [16,17,23-25]. However, other studies have shown that eating more seaweed increased the risk of metabolic syndrome [26]. Meanwhile, no meta-analysis has specifically pooled or summarized the precise effect of algae and its extract consumption on glycolipid metabolism. Therefore, we conducted a meta-analysis to investigate the impact of algae and its extract supplementation on concentrations for glycolipid metabolism in humans.

\section{Methods}

\subsection{Search Strategy}

We have systematically searched several databases, including PubMed, Web of Science, the Cochrane Library and Embase from inception to 1 December 2019. The search terms were as follows: (algae OR seaweed OR kelp OR laminaria japonica OR nori OR wakame OR undaria OR sea mustard OR sea lettuce OR sea kale OR nostoc OR gelidium OR hijiki OR sargassum fusiforme OR hizikia fusiforme OR gracilaria OR ulva clathrate OR spirulina OR chlorella OR algal polysaccharide OR trehalose OR fucoidan OR algae polyphenol OR algae polypeptide OR seaweed peptides) AND (FPG OR insulin OR HOMA-IR OR HbA1c OR HDL-C OR LDL-C OR Triglyceride OR Total cholesterol). All authors were involved in the screening of the inclusion trials.

\subsection{Selection Criteria}

The experiments that meet the requirements of the inclusion criteria were as follows: (1) Randomized controlled trials; (2) RCTs using algae, seaweed polysaccharide, algae polyphenol, algae polypeptide and its products as the intervention, and studies which were combined with other interventions were included when the control group received the same treatment; (3) RCTs using human clinical trials; (4) RCTs that provided information on baseline and post-intervention results for the experimental and control groups. The exclusion criteria were: (1) studies not related to the target research content; (2) studies lacking sufficient results; (3) reviews, letters, comments and abstracts. 


\subsection{Data Extraction}

We extracted the following information from eligible articles: (1) first author's name; (2) publication year; (3) study location; (4) number of participations in experimental and control groups; (5) trial design; (6) intervention duration; (7) daily dose and type of algae and its extracts; (8) age and gender of participants; (9) health status of subjects; (10) levels of lipid profile, FPG, 2hPBG, HOMA-IR, HbA1c and insulin.

\subsection{Quality Assessment and Publication Bias}

We used the Cochrane Collaboration's tool for assessing risk of bias to assess the quality of selected RCTs. Potential publication bias was evaluated by Begg's funnel plot asymmetry, Begg's rank correlation and Egger's weighted regression tests. Additional trim and fill analysis was then performed to test and adjust for publication bias [27].

\subsection{Statistical Methods}

Before the analysis, the study heterogeneity was tested using Cochrane's Q test. An $\mathrm{I}^{2} \geq 50 \%$ and/or a Q-statistic of $p<0.10$ were evidence supporting the presence of heterogeneity [28], in which the random effects modeling method was needed. Otherwise, the fixed effects modeling method was applied. In RCTs reported levels of lipid profile, FBG, and 2hPBG in $\mathrm{mg} / \mathrm{dL}$, the data was converted to $\mathrm{mmol} / \mathrm{L}$ before analyses, and for levels of insulin in $\mu \mathrm{IU} / \mathrm{mL}$, the data was converted to pmol/mL. Effect size of each study was calculated from mean and standard deviation (SD) of the results before and after the intervention and presented as weighted mean difference (WMD) and 95\% confidence interval (CI). In studies that reported the standard error of the mean (SEM), SD was calculated as follows: $\mathrm{SD}=\mathrm{SEM} \times \operatorname{sqrt}(n)$, where $\mathrm{n}$ is the number of subjects. Subgroup analyses were carried out based on intervention duration, sample size, intervention species, health status and area. The intervention duration and the sample size were divided into two subgroups with the boundary of 10 weeks and 40 participants, respectively; the types of interventions were divided into three groups according to spirulina, chlorella and other algae; health status was divided into health people, obesity, type 2 diabetes and other diseases; and the area was divided into three groups: East Asia, Southwest Asia, and non-Asia. Subgroup analysis is not performed on indicators with fewer than 3 studies. The results from our included studies were combined using Stata software version 11.0. $p$ values are two tailed, and $p<0.05$ was considered statistically significant.

\section{Results}

\subsection{Search Results and Characteristics of Studies}

A flow diagram showing the procedure of study selection is presented in Figure 1. From the electronic searches, 1409 potential literature citations and four additional records identified through other sources were identified. In the end, a total of 27 RCTs (30 trials) with 1221 participants were finally considered to be selected for the current meta-analysis [29-55]. The characteristics of RCTs included in the meta-analysis are summarized in Table 1. These included studies published between 1996 and 2019 and conducted in seven countries, including Japan, India, Korea, Mexico, America, Poland and Iran. The number of participants ranged from 12 to 80, and the intervention duration ranged from two weeks to 28 weeks. The subjects were pre-diabetic and patients with type 2 diabetes (T2D), obese or overweight subjects, healthy adults and patients with hyperlipidemia or hypercholesterolemia. Among the included studies, 22 trials used a placebo as the control; other studies used methods of controlling variables. 
Table 1. Characteristics of the included randomized controlled trails (RCTs).

\begin{tabular}{|c|c|c|c|c|c|c|c|c|c|}
\hline First Author (year) & Country & $\begin{array}{c}\text { RCT } \\
\text { Design }\end{array}$ & $\begin{array}{l}\text { Sample } \\
\text { Number }\end{array}$ & $\begin{array}{c}\text { Male } \\
(\%)\end{array}$ & $\begin{array}{c}\text { Age } \\
\text { (year) }\end{array}$ & Health Status & $\begin{array}{l}\text { Intervention } \\
\text { Duration }\end{array}$ & Intervention Products & Main Outcomes \\
\hline Ramamoorthy et al. [51] (1996) & India & NA & 20 & NA & $40-60$ & Hypercholesterolemia subjects & 3 months & Spirulina (2 g/day; $4 \mathrm{~g} /$ day $)$ & TG, TC \\
\hline Parikh et al. [35] (2001) & India & Parallel & 25 & $60 \%$ & $46-61$ & patients with type 2 diabetes & 2 months & Spirulina tablets $(1 \mathrm{~g} /$ day $)$ & $\begin{array}{l}\text { HbA1c, FPG, 2hPBG, LDL-C, } \\
\text { HDL-C, TG, TC }\end{array}$ \\
\hline Samules et al. [50] (2002) & India & Parallel & 23 & $74 \%$ & $3-12$ & $\begin{array}{l}\text { patients with hyperlipidemic } \\
\text { nephrotic syndrome }\end{array}$ & 2 months & $\begin{array}{l}\text { Spray-dried spirulina capsules } \\
\text { (3 g/day) }\end{array}$ & FPG, LDL-C, HDL-C, TG, TC \\
\hline Sansawa et al. [37] (2002) & Japan & NA & 20 & $40 \%$ & $45-64$ & Hyperlipidemia subjects & 3 months & Chlorella (3 g/day) & LDL-C, HDL-C, TG, TC \\
\hline Lee et al. [34] (2008) & Korea & Parallel & 37 & $54 \%$ & $49-56$ & patients with type 2 diabetes & 12 weeks & $\begin{array}{l}\text { Spirulina pills from freeze-dried } \\
\text { spirulina ( } 8 \mathrm{~g} / \text { day })\end{array}$ & $\begin{array}{l}\text { HbA1c, FPG, Insulin LDL-C, } \\
\text { HDL-C, TG, TC }\end{array}$ \\
\hline Park et al. [52] (2008) & Korea & Parallel & $43 ; 36$ & $100 \%$ & $64-68$ & males aged $60-87$; females aged $60-87$ & 16 weeks & Freezedried spirulina pills (8 g/day) & LDL-C, HDL-C, TG, TC \\
\hline Sun et al. [31] (2008) & Korea & NA & 20 & $45 \%$ & $51-58$ & patients with type 2 diabetes & 4 weeks & $\begin{array}{l}\text { Pills with sea tangle and sea mustard } \\
\text { ( } 48 \mathrm{~g} / \text { day) }\end{array}$ & FPG, 2hPBG \\
\hline Anitha et al. [36] (2010) & India & Parallel & 80 & $100 \%$ & $45-60$ & patients with type 2 diabetes & 12 weeks & $\begin{array}{l}\text { Spirulina capsules and diet } \\
\text { modification }(1 \mathrm{~g} / \text { day })\end{array}$ & LDL-C, HDL-C, TG, TC \\
\hline Kwak et al. [46] (2012) & $\begin{array}{c}\text { Korea } \\
\text { Iran }\end{array}$ & $\begin{array}{c}\text { Parallel } \\
\text { NA }\end{array}$ & 51 & $39 \%$ & $30-38$ & healthy subjects & 8 weeks & Chlorella ( $5 \mathrm{~g} /$ day $)$ & LDL-C, HDL-C, TG, TC \\
\hline Panahi et al. [43] (2012) & Iran & NA & 63 & $27 \%$ & $51-73$ & dyslipidemic subjects & 8 weeks & Chlorella and atorvastatin ( $0.6 \mathrm{~g} /$ day $)$ & FPG, LDL-C, HDL-C, TG, TC \\
\hline Miyazawa et al. [45] (2013) & Japan & Parallel & 12 & $58 \%$ & $50-65$ & nomal senior subjects & 2 months & Chlorella (8 g/day) & FPG, LDL-C, HDL-C, TG, TC \\
\hline Diana et al. [54] (2014) & Mexico & Parallel & 21 & $29 \%$ & $38-53$ & overweight or obese adult & 3 months & Fucoidan $(0.5 \mathrm{~g} /$ day $)$ & $\begin{array}{l}\text { FPG, 2hPBG, HOMA-IR, insulin, } \\
\text { LDL-C, TG, TC }\end{array}$ \\
\hline Merhrangiz et al. [42] (2014) & Iran & Parallel & 55 & $55 \%$ & $20-50$ & obese patients with NAFLD & 8 weeks & Chlorella ( $1.2 \mathrm{~g} /$ day $)$ & $\begin{array}{l}\text { FPG, insulin, LDL-C, HDL-C, } \\
\text { TG, TC }\end{array}$ \\
\hline Hong et al. [32] (2015) & Korea & Cross-over & 73 & $71 \%$ & $45-62$ & pre-diabetic adults & 12 weeks & Tablets with AG-dieckol (1.5 g/day) & HbA1c, FPG, 2hPBG, Insulin \\
\hline Maryam et al. [30] (2015) & Iran & Parallel & 49 & $18 \%$ & $48-65$ & patients with type 2 diabetes & 12 weeks & $\begin{array}{c}\text { Capsules of Aogenizomenon extract } \\
\text { ( } 3 \mathrm{~g} / \text { day })\end{array}$ & $\begin{array}{c}\text { HbA1c, FPG, LDL-C, HDL-C, } \\
\text { TG, TC }\end{array}$ \\
\hline Otsuki et al. [44] (2015) & Japan & Parallel & 32 & $41 \%$ & $45-75$ & adult subjects & 4 weeks & Chlorella ( $6 \mathrm{~g} /$ day $)$ & LDL-C, HDL-C, TG \\
\hline Akiko et al. [55] (2016) & Japan & Parallel & 34 & $97 \%$ & $40-56$ & healthy subjects, BMI $\geq 23$ & 16 weeks & Trehalose (10 g/day) & $\begin{array}{l}\text { FPG, 2hPBG, HOMA-IR, insulin, } \\
\text { HbA1c }\end{array}$ \\
\hline Alam et al. [33] (2016) & India & NA & 40 & NA & $35-54$ & patients with type 2 diabetes & 45 days & Spirulina powder (14 g/day) & $\mathrm{HbA1c}$, FPG, 2hPBG \\
\hline Jensen et al. [53] (2016) & America & Parallel & 24 & $21 \%$ & $25-62$ & $\begin{array}{l}\text { adult men and women } 25-65 \text { years } \\
\text { of age }\end{array}$ & 2 weeks & $\begin{array}{l}\text { Phycocyaninenriched aqueous extract } \\
\text { from Spirulina platensis }(2.3 \mathrm{~g} / \text { day })\end{array}$ & FPG \\
\hline Kim et al. [47] (2016) & Korea & Parallel & 34 & $12 \%$ & $22-25$ & healthy subjects & 4 weeks & Chlorella (5 g/day) & LDL-C, HDL-C, TC \\
\hline Park et al. [39] (2016) & Korea & Parallel & $45 ; 33$ & NA & $64-69$ & Non-obese subjects; obese subjects & 12 weeks & Spirulina ( $8 \mathrm{~g} /$ day $)$ & LDL-C, HDL-C, TG, TC \\
\hline Mikami et al. [38] (2017) & Japan & Parallel & $39 ; 40$ & $\begin{array}{l}67 \% \\
73 \%\end{array}$ & $50-60$ & obese subjects, $\mathrm{BMI} \geq 22$ & 8 weeks & Fucoidan ( $1 \mathrm{~g} /$ day; $2 \mathrm{~g} /$ day $)$ & $\begin{array}{l}\text { FPG, insulin, HbA1c, LDL-C, } \\
\text { HDL-C, TC }\end{array}$ \\
\hline Szulinska et al. [48] (2017) & Poland & Parallel & 50 & $50 \%$ & $40-58$ & subjects with treated hypertension & 12 weeks & Spirulina capsules ( $2 \mathrm{~g} /$ day $)$ & LDL-C, HDL-C, TG, TC \\
\hline Zeinalian et al. [49] (2017) & Iran & Parallel & 56 & $16 \%$ & $25-43$ & obese individuals & 12 weeks & $\begin{array}{l}\text { Spirulina platensis supplement } \\
(1 \mathrm{~g} / \text { day })\end{array}$ & LDL-C, HDL-C, TG, TC \\
\hline Yousefi et al. [41] (2018) & Iran & Parallel & 38 & $18 \%$ & $31-51$ & obese and overweight subjects & 12 weeks & Spirulina ( $2 \mathrm{~g} /$ day $)$ & LDL-C, HDL-C, TC \\
\hline Kim et al. [40] (2019) & Korea & Parallel & 78 & $40 \%$ & $27-46$ & obese or overweight individuals & 12 weeks & Gelidium elegans ( $1 \mathrm{~g} /$ day $)$ & $\begin{array}{l}\text { FPG, HOMA-IR, insulin, LDL-C, } \\
\text { HDL-C, TG, TC }\end{array}$ \\
\hline Sakai et al. [29] (2019) & Japan & Cross-over & 30 & $73 \%$ & $30-79$ & patients with type 2 diabetes & 28 weeks & Fucoidan (1.62 g/day) & $\begin{array}{l}\text { HbA1c, FPG, Insulin, LDL-C, } \\
\text { HDL-C, TG, TC }\end{array}$ \\
\hline
\end{tabular}




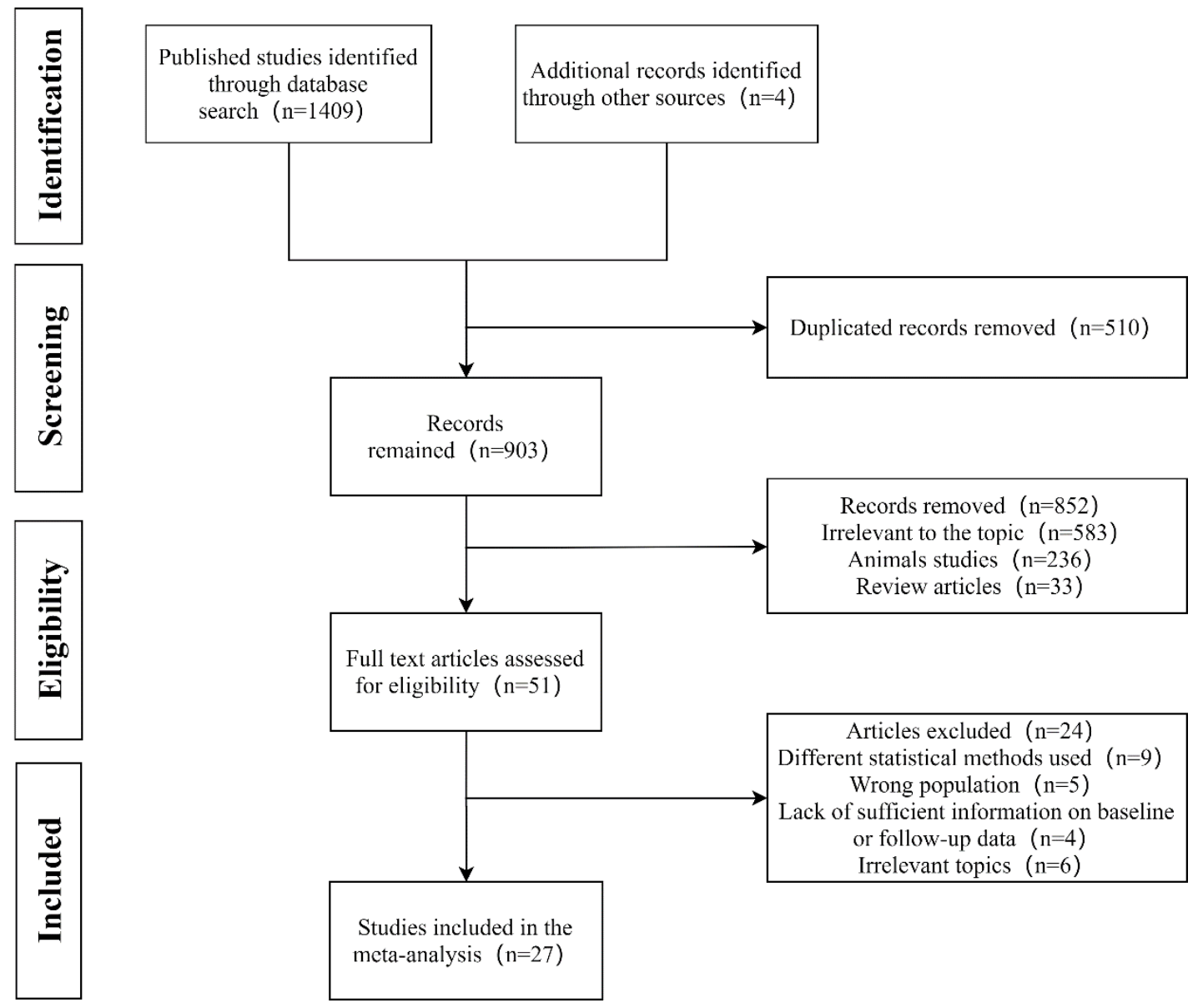

Figure 1. Flowchart of database searches and studies included in the present meta-analysis.

\subsection{Effect of Algae and Its Extracts Intervention on Lipid Profiles}

The meta-analysis was performed on data extracted from 23 RCTs for HDL-C (961 subjects), TG (869 subjects), and 25 RCTs for TC (979 subjects), LDL-C (980 subjects) (Figure 2). The results showed that algae intervention did not significantly change the LDL-C (WMD $=0.04 \mathrm{mmol} / \mathrm{L} ; 95 \% \mathrm{CI}:-0.16$ to $0.24 ; p=0.70 ; I^{2}=97 \%$ ) and TG (WMD $=-0.02 \mathrm{mmol} / \mathrm{L} ; 95 \% \mathrm{CI}:-0.36$ to $0.32 ; p=0.91 ; I^{2}=78 \%$ ). It showed that algae intervention significantly decreased HDL-C (WMD $=-0.22 \mathrm{mmol} / \mathrm{L} ; 95 \% \mathrm{CI}$ : -0.38 to $-0.06 ; p=0.008 ; I^{2}=88 \%$ ) and TC (WMD $=-0.45 \mathrm{mmol} / \mathrm{L} ; 95 \% \mathrm{CI}:-0.67$ to $-0.23 ; p<0.001$; $I^{2}=88 \%$ ). This indicated that HDL-C decreased by an average of $0.22 \mathrm{mmol} / \mathrm{L}$ in the experimental group after intervention compared with the control group, and that TC decreased by an average of $0.45 \mathrm{mmol} / \mathrm{L}$. The high levels of statistical heterogeneity were found in most of the analysis. 


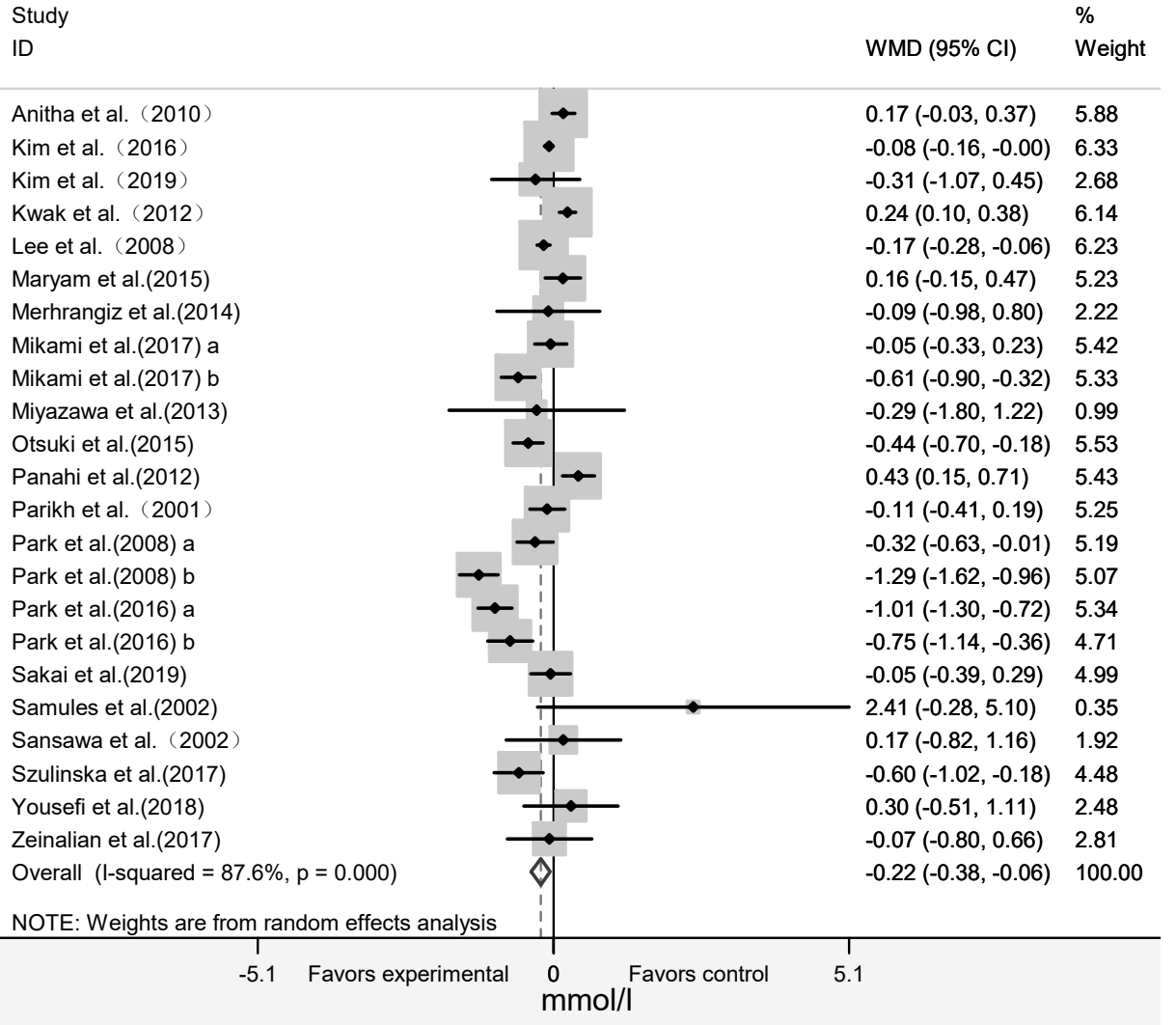

(A)

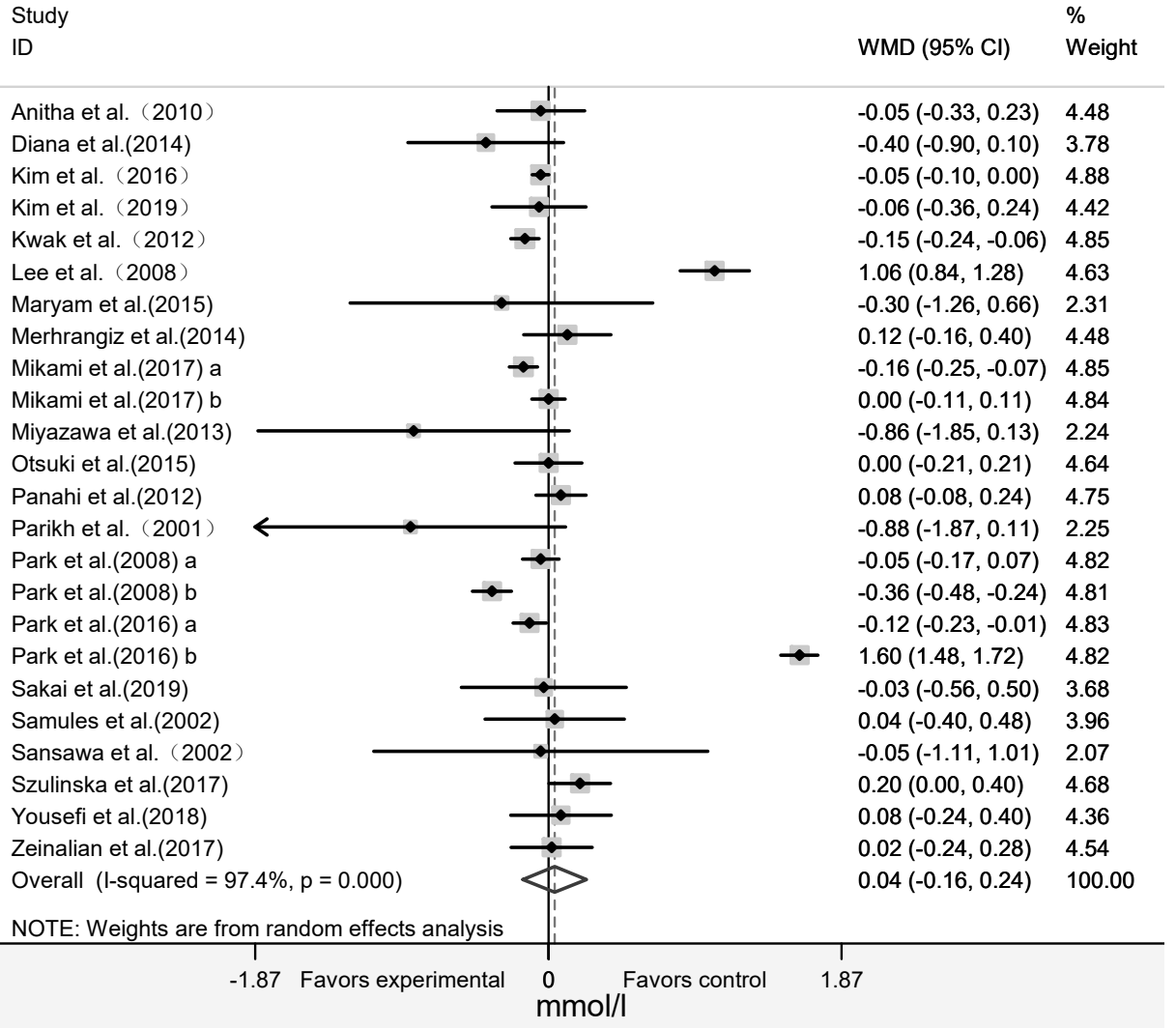

(B)

Figure 2. Cont. 


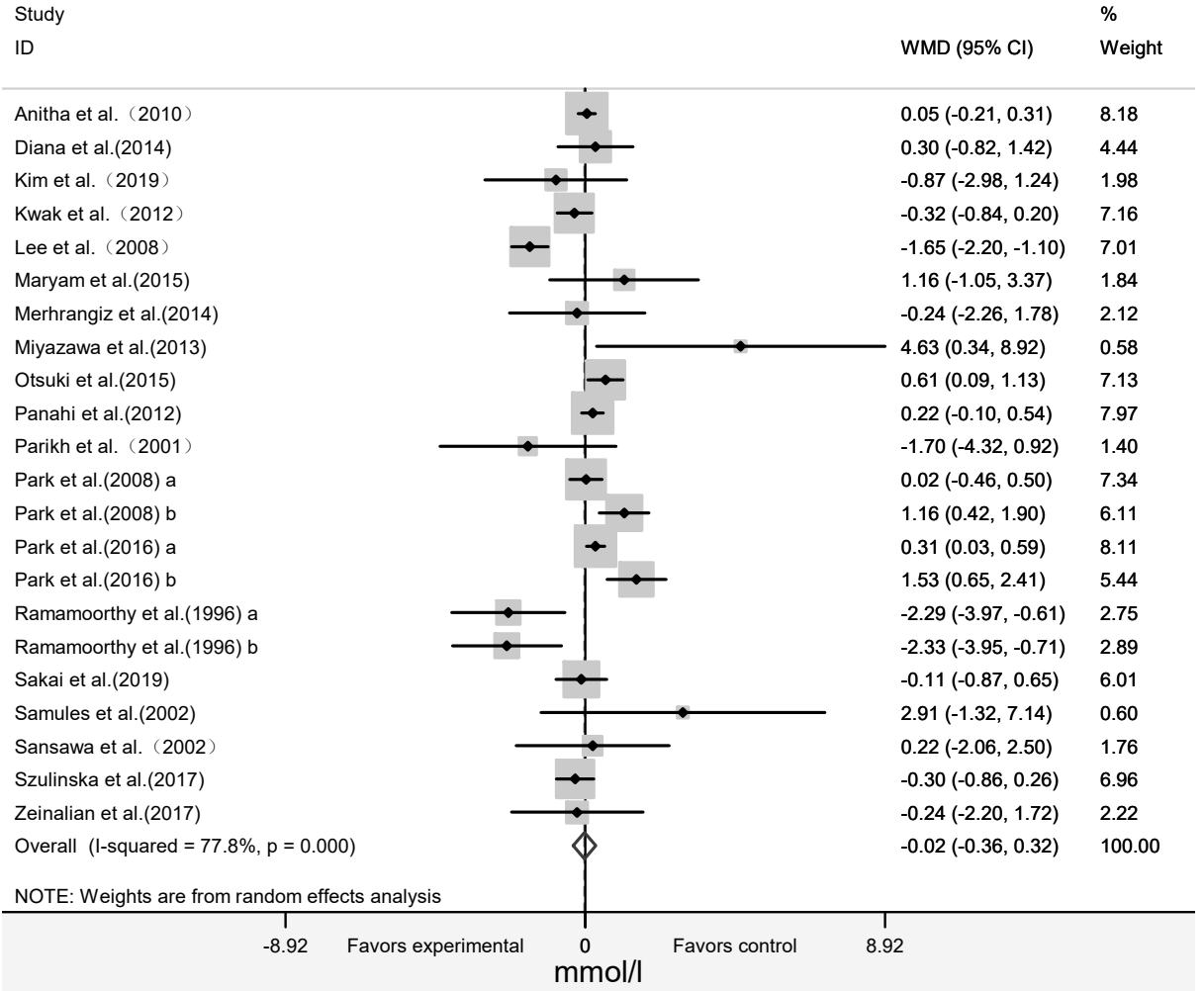

(C)

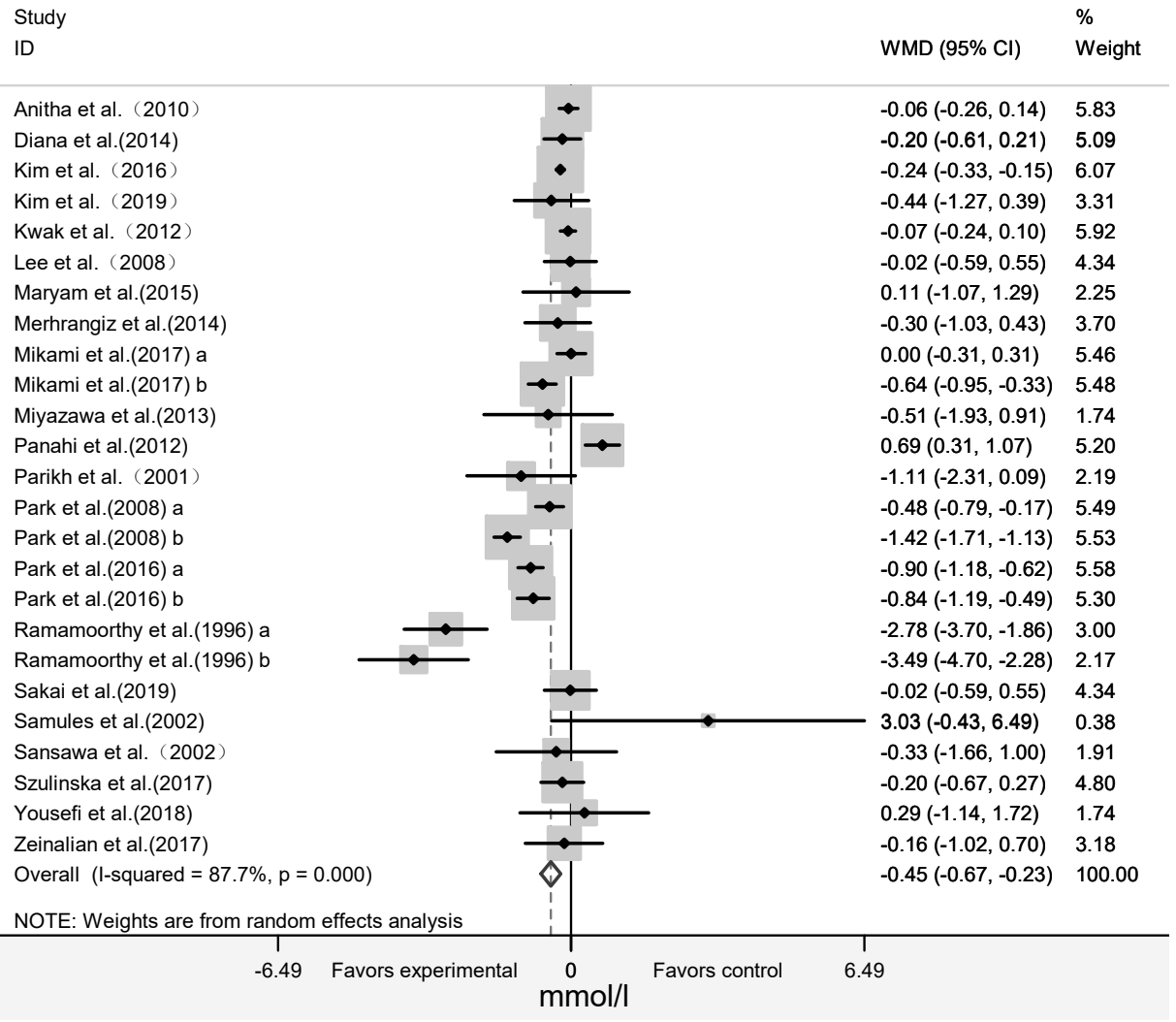

(D)

Figure 2. Forest plot of the effect of algae supplementation on high-density lipoprotein cholesterol (A), low-density lipoprotein cholesterol (B), triglycerides (C), and total cholesterol (D). 
3.3. Effect of Algae and Its Extract Intervention on Fast Plasma Glucose and 2-Hour Postprandial Blood Glucose

The effect of algae supplementation on FPG was evaluated in 17 RCTs with 644 subjects. It showed that algae supplementation did not significantly change FPG (Figure 3A: WMD $=-0.06 \mathrm{mmol} / \mathrm{L}$; 95\% CI: -0.22 to $0.09 ; p=0.42 ; I^{2}=55 \%$ ). The results in six RCTs with 201 subjects showed that algae intervention did not significantly change the 2hPBG (Figure 3B: WMD $=-0.45 \mathrm{mmol} / \mathrm{L} ; 95 \% \mathrm{CI}:-1.85$ to $0.96 ; p=0.53, I^{2}=81 \%$ ).

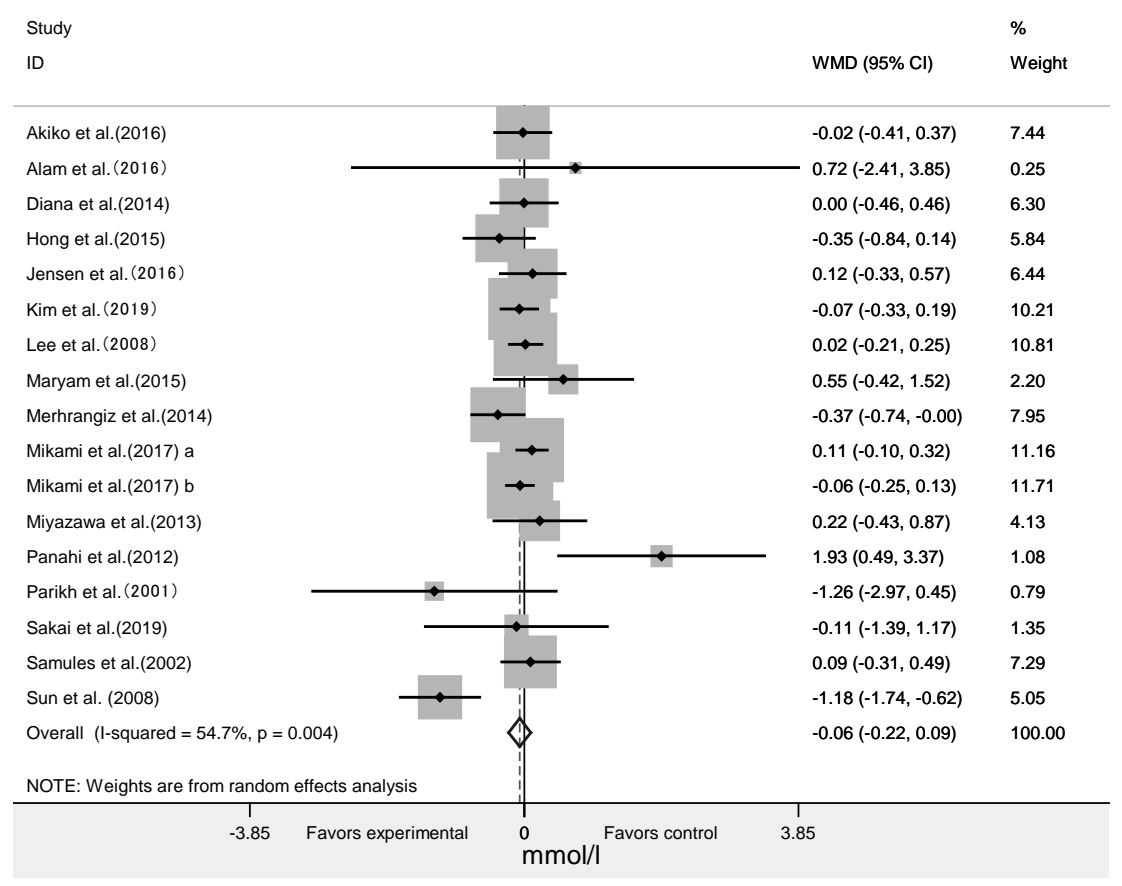

(A)

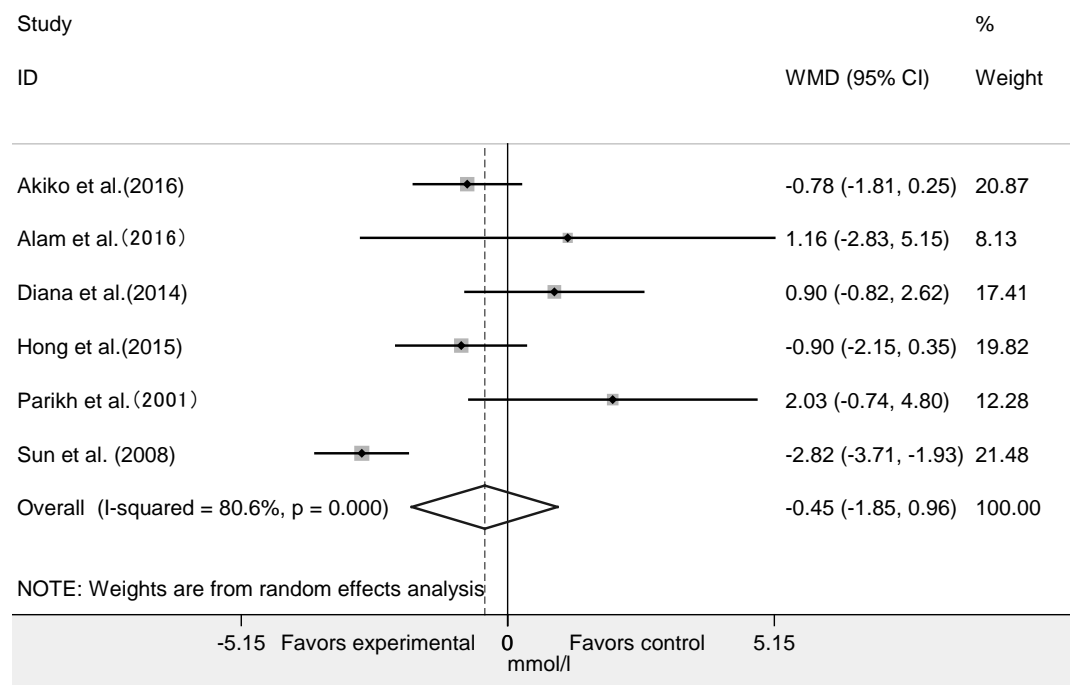

(B)

Figure 3. Forest plot of the effect of algae supplementation on fasting plasma glucose (A) and 2-h post-meal blood glucose (B).

\subsection{Effect of Algae and Its Extracts Intervention on HOMA-IR, Insulin and HbA1c}

The meta-analysis of nine RCTs with 393 participants (Figure 4A) showed that algae supplementation significantly increased serum insulin (WMD $=5.48 \mathrm{pmol} / \mathrm{mL} ; 95 \%$ CI: 3.45 to $7.50 ; p<0.001, I^{2}=78 \%$ ) and 
decreased HbA1c (Figure 5A: WMD $=-0.18 \% ; 95 \% \mathrm{CI}:-0.27$ to $-0.10 ; p<0.001, I^{2}=35 \%$ ). Influence analyses for insulin demonstrated that the heterogeneity belonged to the study of Merhrangiz et al. [42]. Therefore, reanalysis was performed after excluding this study. The inter-study heterogeneity was clearly reduced for insulin $\left(I^{2}=51 \%\right.$, Cochrane $Q$ test $\left.p=0.05\right)$ and it showed that the intervention significantly increased insulin (Figure 4B: WMD = $6.05 \mathrm{pmol} / \mathrm{mL} ; 95 \%$ CI: 4.01 to $8.09 ; p<0.001$; $I^{2}=51 \%$ ) level. It showed that insulin increased by an average of $5.48 \mathrm{pmol} / \mathrm{mL}$ in the experimental group after intervention compared with the control group, and that $\mathrm{HbA} 1 \mathrm{c}$ increased by an average of $0.18 \%$. The five RCTs with 236 subjects showed that there was not a significant change in HOMA-IR (Figure $5 \mathrm{~B}$ : $\mathrm{WMD}=-0.28 ; 95 \% \mathrm{CI}:-0.60$ to $0.03 ; p=0.08, I^{2}=0 \%$ ).

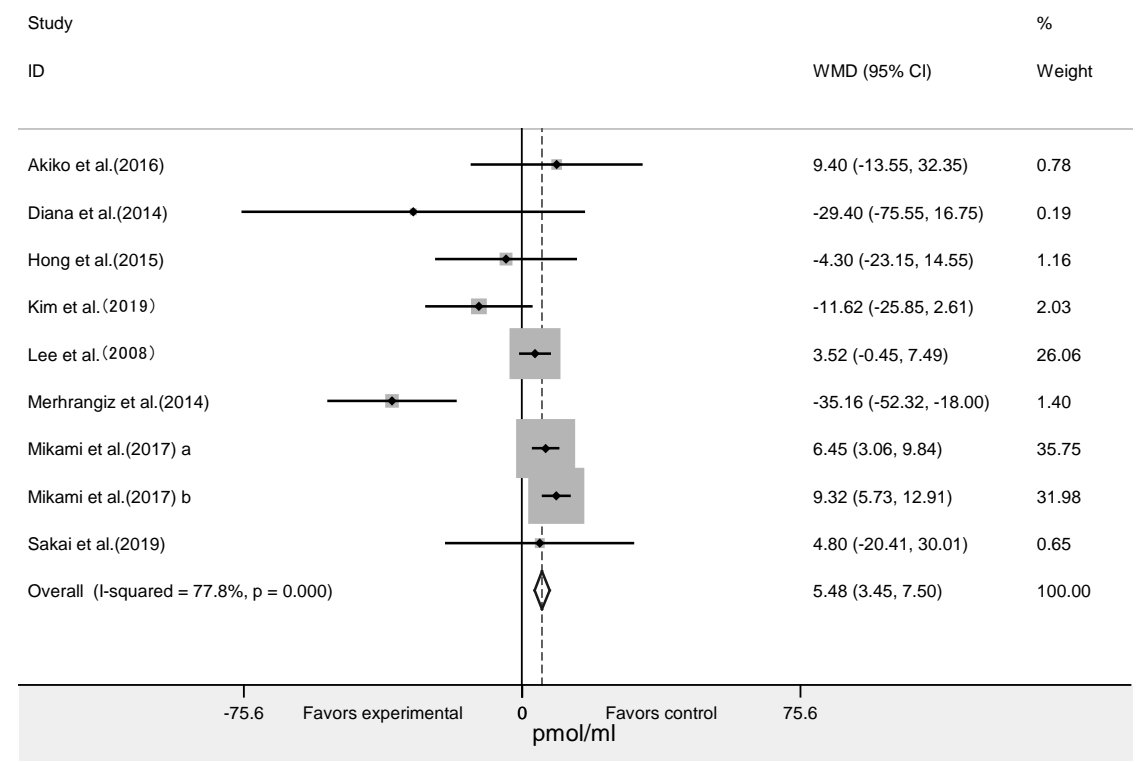

(A)

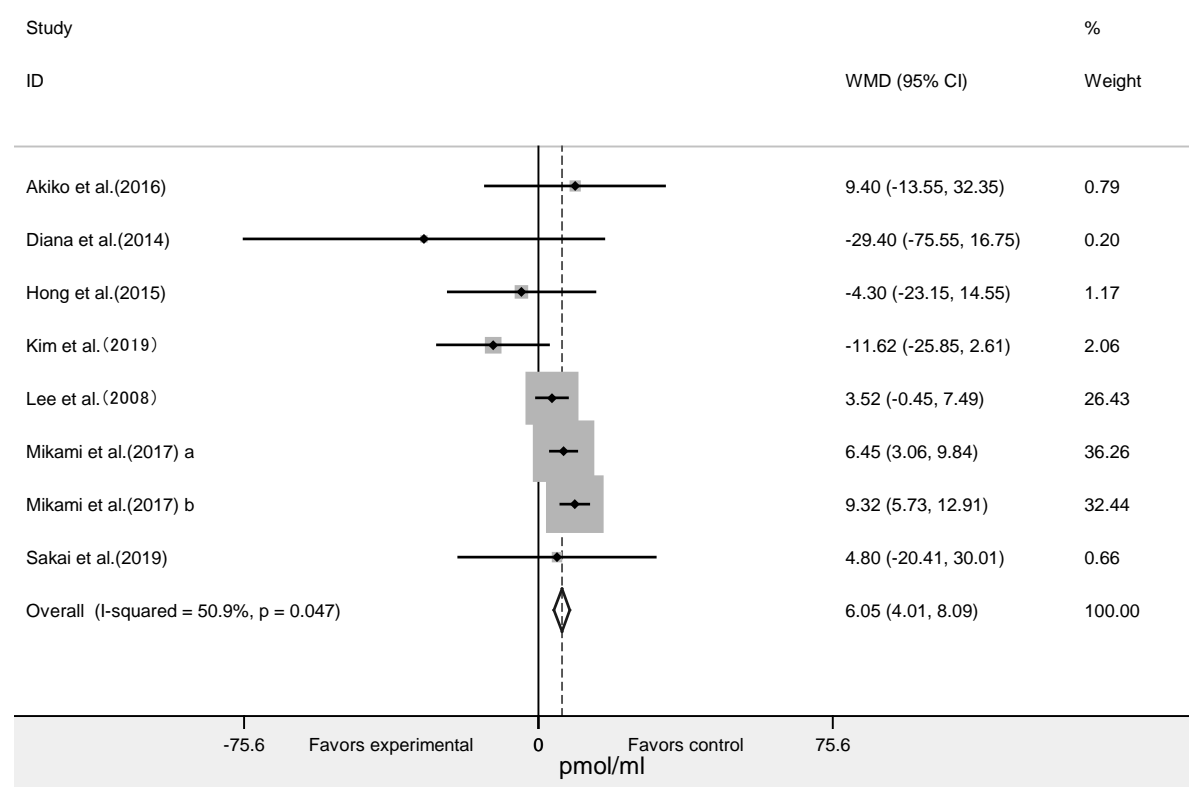

(B)

Figure 4. Forest plot of the effect of algae supplementation on insulin (A) and Leave-one-out sensitivity analysis of the impact of algae supplementation on insulin (B). 


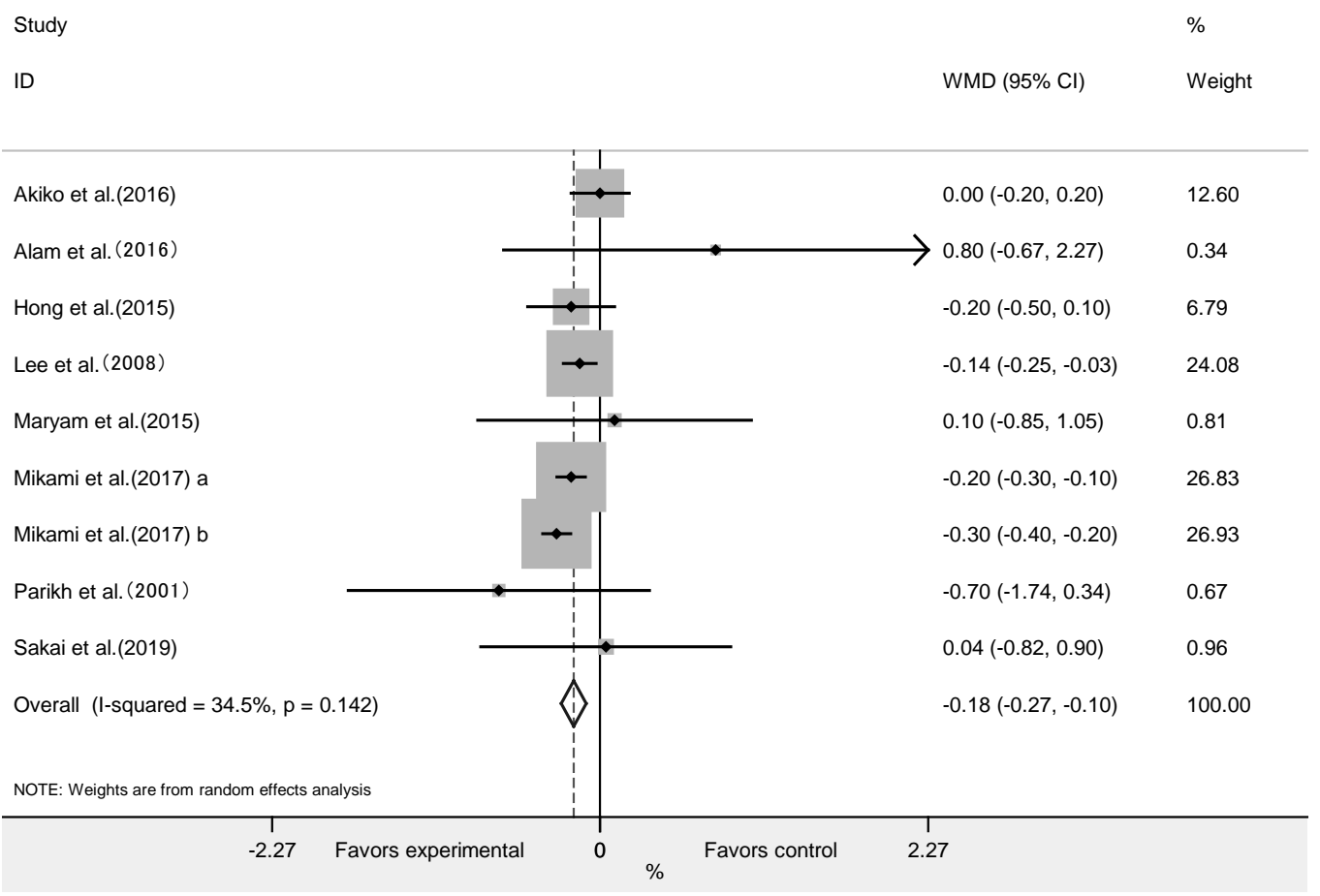

(A)

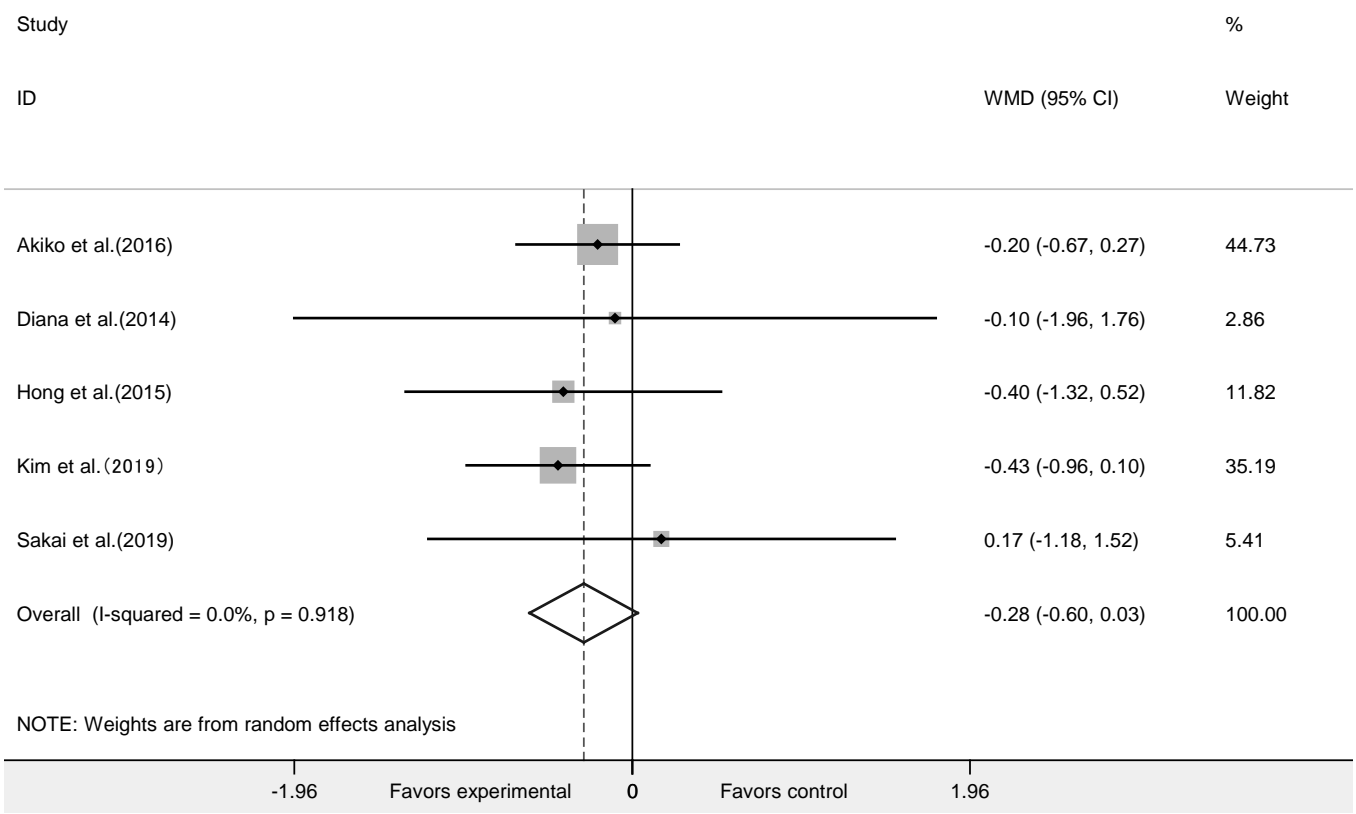

(B)

Figure 5. Forest plot of the effect of algae supplementation on glycosylated hemoglobin (A) and homeostasis model assessment-insulin resistance index (B).

\subsection{Subgroup Analysis}

As is shown in Table 2, the algae and its extract intervention significantly increased the levels of insulin in more than 40 subjects and significantly reduced the levels of 2hPBG in Asian participants (Figure 6). The results of subgroup analysis revealed that algae supplement significantly reduced the HDL-C and TC levels in the subgroup with more than 40 persons and the intervention duration more 
than 10 weeks. It was also found that intervention duration $(<10$ or $>10$ weeks) and sample size $(<40$ or $\geq 40$ people) did not significantly change participants' FPG, LDL-C and TG levels. Algae intervention significantly reduced HDL-C and TC levels in East Asian people, the spirulina intervention group and both in healthy and obese subjects. The intervention significantly increased TG levels in healthy people but the levels of LDL-C were reversed, and it significantly increased other unhealthy people's LDL-C levels (Table 2).

Table 2. Results of the effect of algae and its extracts supplementation on outcomes based on subgroup analyses.

\begin{tabular}{|c|c|c|c|c|c|}
\hline Outcome & Variable & No. of Trials & Effect Size $(95 \%$ CI) & $p$-Value & $I^{2}(\%)$ \\
\hline \multirow{19}{*}{ FPG(mmol/L) } & Intervention duration & & & & \\
\hline & $<10$ weeks & 9 & $-0.087(-0.362,0.189)$ & 0.538 & 71.9 \\
\hline & $>10$ weeks & 6 & $-0.034(-0.173,0.106)$ & 0.636 & 0.0 \\
\hline & Sample size & & & & \\
\hline & $<40$ & 9 & $-0.064(-0.279,0.151)$ & 0.559 & 57.8 \\
\hline & $\geq 40$ & 6 & $-0.073(-0.327,0.181)$ & 0.575 & 53.4 \\
\hline & Intervention species & & & & \\
\hline & Spirulina & 5 & $0.038(-0.142,0.218)$ & 0.680 & 0.0 \\
\hline & Chlorella & 3 & $0.343(-0.592,1.279)$ & 0.472 & 81.1 \\
\hline & Others & 9 & $-0.121(-0.327,0.085)$ & 0.249 & 61.8 \\
\hline & Health condition & & & & \\
\hline & Health & 3 & $0.071(-1.099,0.342)$ & 0.604 & 0.0 \\
\hline & Type 2 diabetes & 7 & $-0.313(-0.817,0.191)$ & 0.223 & 69.7 \\
\hline & Obesity & 5 & $-0.047(-0.181,0.087)$ & 0.491 & 22.7 \\
\hline & Other unhealth conditions & 2 & $0.874(-0.909,2.657)$ & 0.337 & 82.7 \\
\hline & Area & & & & \\
\hline & East Asia & 8 & $-0.011(-0.111,0.090)$ & 0.833 & 0.0 \\
\hline & Non-Asia & 2 & $0.061(-0.263,0.385)$ & 0.711 & 0.0 \\
\hline & Southwest Asia & 7 & $-0.098(-0.710,0.515)$ & 0.754 & 77.7 \\
\hline \multirow{6}{*}{ Insulin(pmol/mL) } & Intervention duration & & & & \\
\hline & $<10$ weeks & 3 & $-0.636(-11.138,9.866)$ & 0.905 & 92.0 \\
\hline & $>10$ weeks & 6 & $-0.299(-7.456,6.858)$ & 0.935 & 25.7 \\
\hline & Sample size & & & & \\
\hline & $<40$ & 4 & $-9.597(29.892,10.697)$ & 0.354 & 90.8 \\
\hline & $\geq 40$ & 5 & $5.157(2.611,7.703)$ & $0.000 *$ & 0.0 \\
\hline \multirow{19}{*}{ HDL-C(mmol/L) } & Intervention duration & & & & \\
\hline & $<10$ weeks & 10 & $-0.068(-0.276,0.139)$ & 0.519 & 83.8 \\
\hline & $>10$ weeks & 13 & $-0.329(-0.595,-0.064)$ & $0.015 *$ & 88.4 \\
\hline & Sample size & & & & \\
\hline & $<40$ & 11 & $-0.158(-0.441,0.124)$ & 0.272 & 89.5 \\
\hline & $\geq 40$ & 12 & $-0.298(-0.507,-0.089)$ & $0.005 *$ & 84.9 \\
\hline & Intervention species & & & & \\
\hline & Spirulina & 11 & $-0.382(-0.683,-0.080)$ & $0.013 *$ & 89.9 \\
\hline & Chlorella & 7 & $0.028(-0.218,0.274)$ & 0.821 & 83.6 \\
\hline & Others & 5 & $-0.158(-0.455,0.140)$ & 0.299 & 73.2 \\
\hline & Health condition & & & & \\
\hline & Health & 7 & $-0.456(-0.817,-0.094)$ & $0.013 *$ & 94.9 \\
\hline & Type 2 diabetes & 5 & $-0.010(-0.181,0.162)$ & 0.912 & 63.8 \\
\hline & Obesity & 7 & $-0.303(-0.600,-0.006)$ & $0.046^{*}$ & 60.0 \\
\hline & Other unhealth conditions & 4 & $0.158(-0.626,0.942)$ & 0.692 & 84.0 \\
\hline & Area & & & & \\
\hline & East Asia & 14 & $-0.368(-0.573,-0.163)$ & $0.000 *$ & 90.7 \\
\hline & Non-Asia & 1 & - & - & - \\
\hline & Southwest Asia & 8 & $0.164(-0.009,0.336)$ & 0.063 & 31.3 \\
\hline
\end{tabular}


Table 2. Cont.

\begin{tabular}{|c|c|c|c|c|c|}
\hline Outcome & Variable & No. of Trials & Effect Size (95\% CI) & $p$-Value & $I^{2}(\%)$ \\
\hline \multirow{19}{*}{$\mathrm{LDL}-\mathrm{C}(\mathrm{mmol} / \mathrm{L})$} & Intervention duration & & & & \\
\hline & $<10$ weeks & 10 & $-0.059(-0.129,0.011)$ & 0.101 & 54.9 \\
\hline & $>10$ weeks & 14 & $0.129(-0.276,0.533)$ & 0.533 & 98.3 \\
\hline & Sample size & & & & \\
\hline & $<40$ & 11 & $0.121(-0.314,0.557)$ & 0.585 & 98.8 \\
\hline & $\geq 40$ & 13 & $-0.028(-0.094,0.039)$ & 0.418 & 42.7 \\
\hline & Intervention species & & & & \\
\hline & Spirulina & 12 & $0.125(-0.315,0.564)$ & 0.579 & 98.5 \\
\hline & Chlorella & 7 & $-0.043(-0.129,0.042)$ & 0.321 & 46.8 \\
\hline & Others & 5 & $-0.084(-0.179,0.011)$ & 0.082 & 26.3 \\
\hline & Health condition & & & & \\
\hline & Health & 7 & $-0.132(-0.224,-0.039)$ & $0.005 *$ & 76.6 \\
\hline & Type 2 diabetes & 5 & $0.036(-0.670,0.743)$ & 0.919 & 98.9 \\
\hline & Obesity & 8 & $0.158(-0.401,0.716)$ & 0.581 & 98.9 \\
\hline & Other unhealth conditions & 4 & $0.119(0.001,0.238)$ & $0.048^{*}$ & 0.0 \\
\hline & Area & & & & \\
\hline & East Asia & 14 & $0.095(-0.184,0.373)$ & 0.701 & 98.5 \\
\hline & Non-Asia & 2 & $-0.055(-0.636,0.526)$ & 0.853 & 79.5 \\
\hline & Southwest Asia & 8 & $0.042(-0.059,0.144)$ & 0.413 & 0.0 \\
\hline \multirow{19}{*}{ TG(mmol/L) } & Intervention duration & & & & \\
\hline & $<10$ weeks & 7 & $0.186(-0.345,0.717)$ & 0.493 & 57.6 \\
\hline & $>10$ weeks & 15 & $-0.112(-0.551,0.326)$ & 0.616 & 82.3 \\
\hline & Sample size & & & & \\
\hline & $<40$ & 11 & $-0.110(-1.123,0.902)$ & 0.831 & 86.9 \\
\hline & $\geq 40$ & 11 & $0.116(-0.058,0.289)$ & 0.190 & 22.5 \\
\hline & Intervention species & & & & \\
\hline & Spirulina & 11 & $-0.266(-0.940,0.408)$ & 0.439 & 87.6 \\
\hline & Chlorella & 7 & $0.151(-0.155,0.456)$ & 0.335 & 46.4 \\
\hline & Others & 4 & $0.030(-0.549,0.609)$ & 0.919 & 0.0 \\
\hline & Health condition & & & & \\
\hline & Health & 8 & $0.463(0.017,0.909)$ & $0.042 *$ & 73.1 \\
\hline & Type 2 diabetes & 5 & $-0.472(-1.451,0.507)$ & 0.345 & 87.9 \\
\hline & Obesity & 3 & $0.091(-0.782,0.965)$ & 0.838 & 0.0 \\
\hline & Other unhealth conditions & 6 & $-0.558(-1.412,0.297)$ & 0.201 & 74.7 \\
\hline & Area & & & & \\
\hline & East Asia & 11 & $0.183(-0.366,0.751)$ & 0.514 & 86.0 \\
\hline & Non-Asia & 2 & $-0.180(-0.679,0.318)$ & 0.478 & 0.0 \\
\hline & Southwest Asia & 9 & $-0.294(-0.848,0.259)$ & 0.297 & 62.6 \\
\hline \multirow{18}{*}{$\mathrm{TC}(\mathrm{mmol} / \mathrm{L})$} & Intervention duration & & & & \\
\hline & $<10$ weeks & 9 & $-0.128(-0.383,0.127)$ & 0.325 & 79.6 \\
\hline & $>10$ weeks & 16 & $-0.646(-0.991,-0.300)$ & $0.000 *$ & 88.0 \\
\hline & Sample size & & & & \\
\hline & $<40$ & 11 & $-0.242(-0.513,0.030)$ & 0.082 & 83.5 \\
\hline & $\geq 40$ & 14 & $-0.700(-1.101,-0.299)$ & $0.001 *$ & 90.0 \\
\hline & Intervention species & & & & \\
\hline & Spirulina & 13 & $-0.803(-1.223,-0.383)$ & $0.000 *$ & 90.1 \\
\hline & Chlorella & 6 & $-0.016(-0.310,0.278)$ & 0.914 & 79.0 \\
\hline & Others & 6 & $-0.242(-0.518,0.034)$ & 0.085 & 48.6 \\
\hline & Health condition & & & & \\
\hline & Health & 5 & $-0.692(-1.269,-0.115)$ & $0.019 *$ & 94.3 \\
\hline & Type 2 diabetes & 5 & $-0.072(-0.250,0.107)$ & 0.432 & 0.0 \\
\hline & Obesity & 9 & $-0.346(-0.553,-0.140)$ & $0.001 *$ & 59.2 \\
\hline & $\begin{array}{l}\text { Other unhealth conditions } \\
\text { Area }\end{array}$ & 6 & $-0.810(-2.137,0.516)$ & 0.231 & 94.0 \\
\hline & East Asia & 13 & $-0.475(-0.723,-0.226)$ & $0.000 *$ & 88.0 \\
\hline & Non-Asia & 2 & $-0.200(-0.507,0.107)$ & 0.202 & 0.0 \\
\hline & Southwest Asia & 10 & $-0.582(-1.276,0.113)$ & 0.101 & 89.6 \\
\hline
\end{tabular}

Notes: * Indicates a significant result. 


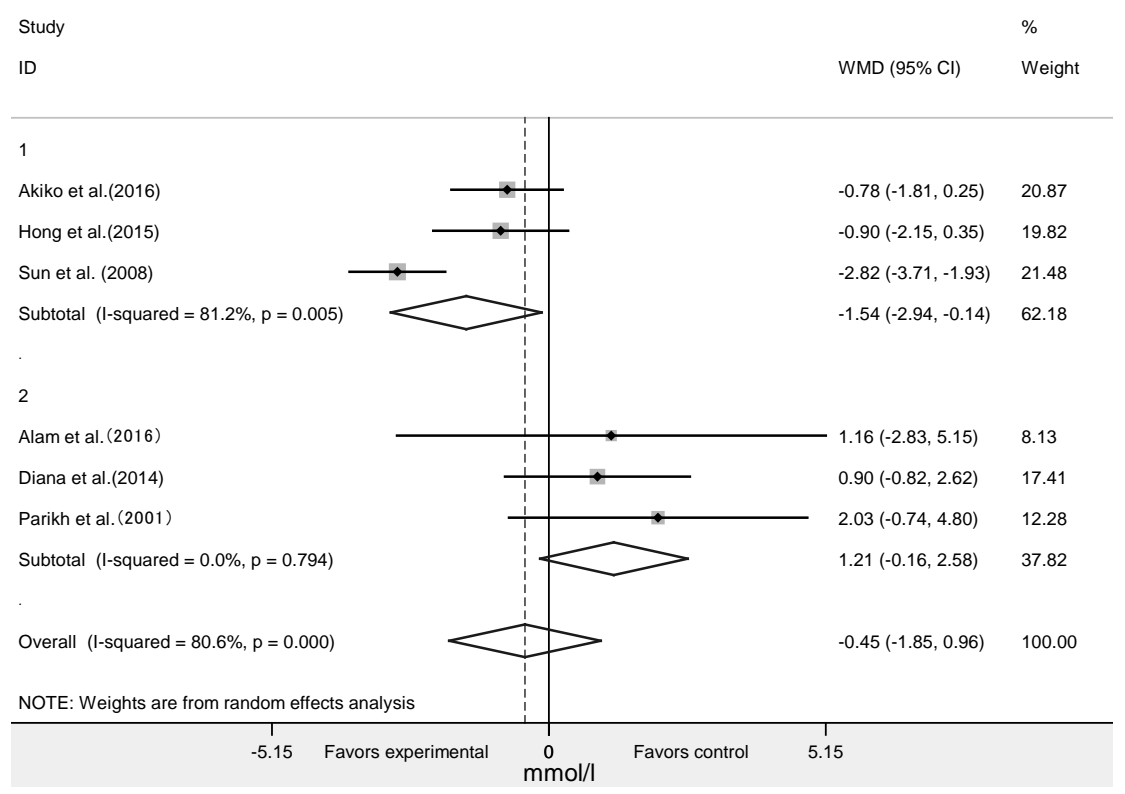

Figure 6. Forest plot of the effect of algae supplementation on 2hPBG in different regions.

\subsection{Publication Bias}

No significant publication bias was found in the inspection of the funnel plot (Figure S3). Similarly, Begg's ranking correlation and Egger's linear regression test were also performed to confirm publication bias. Table 3 lists the results of the Begg's test and the Egger's test. These results did not show any evidence of publication bias in this analysis (all $p>0.05$ ).

Table 3. Publication bias in the meta-analysis of studies.

\begin{tabular}{ccccccc}
\hline \multirow{2}{*}{ Outcomes } & Begg's Rank Correlation Test & \multicolumn{3}{c}{ Egger's Linear Regression Test } \\
\cline { 2 - 7 } & $\mathbf{Z}$ Value & $\boldsymbol{p}$-Value & Intercept (95\% CI) & $\mathbf{t}$ & $\mathbf{d f}$ & $\boldsymbol{p}$-Value \\
\hline FPG & 0.29 & 0.773 & $-0.04(-1.51,1.44)$ & -0.05 & 16 & 0.959 \\
2hPBG & 1.13 & 0.260 & $3.77(-0.71,8.24)$ & 2.34 & 5 & 0.080 \\
HOMA-IR & 0.24 & 0.806 & $0.40(-1.26,2.06)$ & 0.76 & 4 & 0.503 \\
Insulin & 0.73 & 0.466 & $-1.92(-4.02,0.19)$ & -2.16 & 8 & 0.068 \\
HbA1c & 0.89 & 0.371 & $1.34(-0.86,3.54)$ & 1.41 & 9 & 0.197 \\
HDL-C & 0.21 & 0.833 & $-0.88(-2.84,1.07)$ & -0.94 & 22 & 0.360 \\
LDL-C & 0.72 & 0.472 & $0.66(-3.69,5.02)$ & 0.31 & 24 & 0.756 \\
TG & 0.11 & 0.910 & $-0.26(-1.81,1.28)$ & -0.36 & 22 & 0.726 \\
TC & 0.61 & 0.544 & $-0.89(-2.65,0.87)$ & -1.04 & 24 & 0.307 \\
\hline
\end{tabular}

\section{Discussion}

Our research showed that algae intervention improved glucolipid metabolism, showing that algae intervention could be effective in improving T2D and CVD. The results of our meta-analysis revealed a significant effect of supplementation with algae and its extracts in reducing $\mathrm{HbA1c}$, TC and HDL-C levels. It also showed significant effects in increasing insulin levels. The combined results are robust and remain significant in the missing sensitivity analysis (Figures S1 and S2). Our results are similar to the study performed by Haohai et al. [56]. In addition, another meta-analysis showed similar results [57], but the results of HDL-C were the opposite. Non-insulin-dependent or type 2 diabetes is often a result of prolonged obesity, usually presenting concomitantly with impaired glucose tolerance, hypertension, and hyperlipidemia [10]. Specific goals of medical nutrition therapy for diabetics included reaching and maintaining near-normal blood glucose levels, achieving optimal blood lipid levels, consuming enough calories to achieve a reasonable body weight, and improving 
overall healthy nutrients by maintaining a balanced macro- and micro-intake [58,59]. Therefore, the algae intervention was beneficial to diabetics by improving their glucose metabolism and lipid distribution indicators. Meanwhile, dyslipidemia, hypertension, hyperglycemia, and high level of $\mathrm{HbA} 1 \mathrm{c}$ are considered to be the key risk factors for atherosclerotic cardiovascular disease in humans. There is sufficient evidence to show that the potential role of lipid-lowering treatment interventions is to reduce the risk of atherosclerosis. Seaweed is rich in dietary fiber, and there is evidence that some soluble fibers bind to bile acids or cholesterol during the formation of the micellar cavity $[60,61]$. The resulting reduction in hepatocellular cholesterol leads to an upregulation of LDL receptors, which increases LDL cholesterol clearance. Edible seaweed is rich in non-starch polysaccharides (dietary fiber), protein, minerals and vitamins. The majority of studies have shown satisfactory results in the use of Undaria spp. in animal studies of diabetes, including improved blood lipids status, reduced inflammatory responses, reduced weight gain, and adjusted blood glucose $[62,63]$. Other possible mechanisms include inhibition of fermentation products (production of short-chain fatty acids such as acetic acid, butyric acid, and propionate) to synthesize liver fatty acids; changes in intestinal motility; high-viscosity fibers lead to absorption of macronutrients reducing and insulin sensitivity increasing; increased satiety leading to lower energy intake [61].

In our subgroup analysis, lipid modification of algae intervention was also found in subjects with $>10$ weeks intervention and participants $\geq 40$. The subgroup analysis results showed that algae intervention significantly reduced TC and LDL-C levels in healthy people and significantly reduced LDL-C levels in obese and overweight people. This further confirmed the improvement effect of algae intervention on lipid metabolism. The results of HDL-C and its subgroup analysis were contrary to expectations. The previous study [56] summarized the possible links between spirulina intervention and blood lipids. After the inclusion of chlorella and other algae or its extracts, the effect of algae interventions on HDL-C is unclear, so further clinical trials are needed to verify its effect on HDL-C. Similarly, the elevated role of LDL-C in other unhealthy populations and TG in healthy populations was contrary to expectations. Existing studies have included populations with different health conditions, so it is difficult to judge the health effects of algae interventions with different health conditions. We performed a subgroup analysis of people with different health conditions, but the results were not uniform, except for lipid metabolism. This indicates that further clinical studies on different healthy people are needed to explore the effect of algae intervention on lipid metabolism. Meanwhile, it showed significant change in reducing LDL-C levels of the longer intervention time ( $>10$ weeks) and the larger number participants $(\geq 40)$, which has guiding significance for future clinical trials. For the intervention species, spirulina has the significant effect on reducing TC similar with previous studies [56,57]. Studies have shown that the hypocholesterolemic effects of spirulina concentrates 24 may include inhibiting jejunal cholesterol absorption and ileal bile acid reabsorption, as well as increasing fecal cholesterol and bile acid excretion [64,65]. In addition, C-phycocyanin, the main component of spirulina, can reduce lipid concentration through eliminating free radicals, inhibiting lipid peroxidation, inhibiting nicotinamide adenine dinucleotide phosphate oxidase expression, increasing lipoprotein lipase and liver triglyceride lipase, glycated serum protein peroxidase and superoxide dismutase activities [66-68]. Moreover, the algae supplement can significantly reduce TC levels in East Asian populations, which suggests that algae intervention may be more effective for East Asians.

The results of our meta-analysis demonstrate that algae and its extract intervention could statistically reduce $2 \mathrm{hPBG}$ after treatment in Asian people. It suggested that algae intervention might be more effective for East Asians. For every 1\% increase in glycated hemoglobin ( $\mathrm{HbA1c}$ ) concentration, the risk of coronary heart disease increased by $11 \%$ [69]. It was reported that consuming diets rich in soluble and insoluble fiber produces satiety, could improve glycemic control and reduce total energy intake, adiposity and blood lipids [70,71]. Edible seaweed is rich in non-starch polysaccharides, protein, minerals and vitamins, while low in lipids, which provides fewer calories [72,73]. Even though seaweed can interfere with the bioavailability of other dietary ingredients [74,75], seaweed polysaccharides, which cannot be fully digested by intestinal enzymes, could be considered to be the sources of dietary 
fiber. It was hypothesized that the hypoglycemic mechanism of seaweed occurs because the fiber in seaweed delays the absorption of glucose and lipid, thus improving glucolipid metabolism. Meanwhile, spirulina is a rich source of protein and could provide quality protein. Protein and amino acids are known to stimulate insulin production. This effect might be responsible for lowering postprandial blood glucose levels [76,77].

The present meta-analysis has some limitations. Firstly, there is a high degree of heterogeneity between studies, which have not been addressed through extensive subgroup and sensitivity analysis. The source of heterogeneity might be due to differences in study design, the number of participants and baseline characteristics (age, sex, body mass index). Secondly, the quality of the included studies is uneven. Some trials were lacking the information in random sequence generation and types of blinding. These factors may cause imprecise results. Thirdly, although extensive searches and clear inclusion criteria have been developed, we may not have fully identified all relevant articles related to the use of seaweed intervention, especially unpublished trials and grey literature. According to the clinical practice guidelines, LDL-C is considered the main target of lipid-lowering treatment. The lipid-modifying effects of algae were established in our present meta-analysis in TC. However, there was no significant statistical significance in other lipid profiles. Our race was limited to Asian populations, with only three non-Asia studies and there was no population representative. Finally, the biological mechanisms driving metabolic changes may be distinctly different among different studies. At the same time, the degree of processing of the intervention supplements was various in different studies, and the metabolic mechanism was also different. This is the main limitation and one of the sources of our heterogeneity.

To our knowledge, the current meta-analysis is the first to assess the effects of algae and its extracts on glucose and lipid metabolism from RCTs. Grade analyses demonstrated that the quality of the result for all estimates was moderate. The advantage of this meta-analysis is that the results may be reliable because of evidence of low heterogeneity in eligible studies. Therefore, this study can reduce the controversy of the relationship between algae and its extracts and glucose and lipid metabolism.

\section{Conclusions}

The results indicated that seaweed intervention improved levels of insulin and reduced levels of HbA1c and TC levels, but the changes in other lipid profiles, FPG, HOMA-IR were not statistically significant. Our study also demonstrated that an intervention duration of 10 weeks or higher and participants of 40 or more are more useful. It revealed that seaweed intervention may be more effective for East Asians. Moreover, seaweed supplementation is useful for healthy or obese subjects. The combined results showed a significant clinical improvement in CVD and T2D risk. Seaweed consumption may be considered as an adjunct to the prevention and treatment of cardiovascular disease and type 2 diabetes in humans. Therefore, more precise RCTs on subjects with different health status and different races is recommended to clarify the effect of seaweed, seaweed polysaccharide, seaweed polypeptide, algae polyphenol and its products' intervention on glycolipid metabolism to estimate the effects of CVD and type 2 diabetes.

Supplementary Materials: The following are available online at http://www.mdpi.com/2072-6643/12/6/1712/s1, Figure S1: Quality assessment of the included studies. labeling an item as a "question mark" indicated an unclear or unknown risk of bias; labeling an item as a "negative sign" indicated a high risk of bias; labeling an item as a "positive sign" indicated a low risk of bias, Figure S2: Sensitivity analysis was conducted on outcomes of FPG (A), 2hPBG (B), insulin (C), HOMA-IR (D), HbA1c (E), HDL-C (F), LDL-C (G), TG (H) and TC (I) using the leave-one-out method, Figure S3: Funnel plots with pseudo 95\% CIs for publication bias of FPG (A), 2hPBG (B), insulin (C), HOMA-IR (D), HbA1c (E), HDL-C (F), LDL-C (G), TG (H) and TC (I).

Author Contributions: Conceptualization, K.-x.D., T.-1.G., R.X., J.C., H.-q.Z., Y.-y.S., F.Z., A.-g.M.; methodology, K.-x.D., T.-1.G., R.X., J.C., H.-q.Z., Y.-y.S., F.Z., A.-g.M.; validation, K.-x.D., T.-1.G., R.X., J.C., H.-q.Z., Y.-y.S., F.Z., A.-g.M.; software, K.-x.D.; formal analysis, K.-x.D. and reviewed by T.-l.G; writing-original draft preparation, K.-x.D., T.-1.G.; writing-review and editing, R.X., J.C., H.-q.Z., Y.-y.S.; data curation, F.Z., A.-g.M. All authors have read and agreed to the published version of the manuscript. 
Funding: This research was funded by National Natural Science Foundation of China (NSFC: 81903305); National Natural Science Foundation of China (NSFC: 81803225) and the National Natural Science Foundation of China (NSFC: 81872610).

Conflicts of Interest: The authors declare no conflict of interest.

\section{Abbreviations}

$\begin{array}{ll}\text { FPG } & \text { fasting plasma glucose } \\ \text { NA } & \text { not applicable } \\ \text { TG } & \text { triglycerides } \\ \text { TC } & \text { total cholesterol } \\ \text { HbA1c } & \text { glycosylated hemoglobin } \\ \text { FPG } & \text { fasting plasma glucose } \\ \text { 2hPBG } & \text { 2-h post-meal blood glucose } \\ \text { LDL-C } & \text { low-density lipoprotein cholesterol } \\ \text { HDL-C } & \text { high-density lipoprotein cholesterol } \\ \text { HOMA-IR } & \text { homeostasis model assessment-insulin resistance index }\end{array}$

\section{References}

1. Mathers, C.D.; Loncar, D. Projections of Global Mortality and Burden of Disease from 2002 to 2030. PLoS Med. 2006, 3, e442. [CrossRef]

2. Cameron, A.; E Shaw, J.; Zimmet, P.Z. The metabolic syndrome: Prevalence in worldwide populations. Endocrinol. Metab. Clin. N. Am. 2004, 33, 351-375. [CrossRef]

3. Smith, S.C.; Collins, A.; Ferrari, R.; Holmes, D.R.; Logstrup, S.; McGhie, D.V.; Ralston, J.; Sacco, R.L.; Stam, H.; Taubert, K.; et al. Our Time: A Call to Save Preventable Death from Cardiovascular Disease (Heart Disease and Stroke). J. Am. Coll. Cardiol. 2012, 60, 2343-2348. [CrossRef]

4. Aviram, M. Atherosclerosis: Cell biology and lipoproteins-Inflammation and oxidative stress in atherogenesis: Protective role for paraoxonases. Curr. Opin. Lipidol. 2011, 22, 243-244. [CrossRef]

5. Scannapieco, F.; Bush, R.B.; Paju, S. Associations between Periodontal Disease and Risk for Atherosclerosis, Cardiovascular Disease, and Stroke. A Systematic Review. Ann. Periodontol. 2003, 8, 38-53. [CrossRef]

6. Drash, A. Atherosclerosis, cholesterol, and the pediatrician. J. Pediatr. 1972, 80, 693-696. [CrossRef]

7. Kumagai, H.; Sakurai, M.; Takita, T.; Maruyama, Y.; Uno, S.; Ikegaya, N.; Kato, A.; Hishida, A. Association of Homocysteine and Asymmetric Dimethylarginine With Atherosclerosis and Cardiovascular Events in Maintenance Hemodialysis Patients. Am. J. Kidney Dis. 2006, 48, 797-805. [CrossRef]

8. Neimann, A.L.; Shin, D.B.; Wang, X.; Margolis, D.J.; Troxel, A.; Gelfand, J.M. Prevalence of cardiovascular risk factors in patients with psoriasis. J. Am. Acad. Dermatol. 2006, 55, 829-835. [CrossRef]

9. Haffner, S.M. Coronary Heart Disease in Patients with Diabetes. N. Engl. J. Med. 2000, 342, 1040-1042. [CrossRef]

10. Shim, U.; Lee, H.; Oh, J.-Y.; Sung, Y.-A. Sleep Disorder and Cardiovascular Risk Factors among Patients with Type 2 Diabetes Mellitus. Korean J. Intern. Med. 2011, 26, 277-284. [CrossRef]

11. Cho, N.; Shaw, J.E.; Karuranga, S.; Huang, Y.; Fernandes, J.D.D.R.; Ohlrogge, A.; Malanda, B. IDF Diabetes Atlas: Global estimates of diabetes prevalence for 2017 and projections for 2045. Diabetes Res. Clin. Pract. 2018, 138, 271-281. [CrossRef]

12. Abdul, Q.A.; Choi, R.J.; Jung, H.A.; Choi, J.S. Health benefit of fucosterol from marine algae: A review. J. Sci. Food Agric. 2016, 96, 1856-1866. [CrossRef]

13. Montero, L.; Sánchez-Camargo, A.D.P.; Ibáñez, E.; Gilbert-López, B.; Ibáñez, E. Phenolic Compounds from Edible Algae: Bioactivity and Health Benefits. Curr. Med. Chem. 2019, 25, 4808-4826. [CrossRef]

14. Catarino, M.D.; Silva, A.; Cardoso, S.M. Phycochemical Constituents and Biological Activities of Fucus spp. Marine Drugs 2018, 16, 249. [CrossRef]

15. Sørensen, L.E.; Jeppesen, P.B.; Christiansen, C.B.; Hermansen, K.; Gregersen, S. Nordic Seaweed and Diabetes Prevention: Exploratory Studies in KK-Ay Mice. Nutrition 2019, 11, 1435. [CrossRef]

16. Iso, H. Lifestyle and Cardiovascular Disease in Japan. J. Atheroscler. Thromb. 2011, 18, 83-88. [CrossRef]

17. Kim, J.; Shin, A.; Lee, J.-S.; Youn, S.; Yoo, K.-Y. Dietary Factors and Breast Cancer in Korea: An Ecological Study. Breast J. 2009, 15, 683-686. [CrossRef] 
18. Deng, R.; Chow, T.-J. Hypolipidemic, Antioxidant, and Antiinflammatory Activities of Microalgae Spirulina. Cardiovasc. Ther. 2010, 28, e33-e45. [CrossRef]

19. Martínez-Galero, E.; Pérez-Pastén-Borja, R.; Perez-Juarez, A.; Favila-Castillo, L.; Gutiérrez-Salmeán, G.; Chamorro, G. Preclinical antitoxic properties of Spirulina (Arthrospira). Pharm. Biol. 2015, 54, 1-9. [CrossRef]

20. Karkos, P.D.; Leong, S.C.; Karkos, C.D.; Sivaji, N.; Assimakopoulos, D.A. Spirulina in Clinical Practice: Evidence-Based Human Applications. Evid. Based Complement. Altern. Med. 2010, 2011, 1-4. [CrossRef]

21. Lee, H.; Lu, Y.A.; Li, X.; Hyun, J.-M.; Kim, H.-S.; Lee, J.J.; Kim, T.H.; Kim, H.M.; Kang, M.-C.; Jeon, Y.-J.; et al. Anti-Obesity Effects of Grateloupia elliptica, a Red Seaweed, in Mice with High-Fat Diet-Induced Obesity via Suppression of Adipogenic Factors in White Adipose Tissue and Increased Thermogenic Factors in Brown Adipose Tissue. Nutrition 2020, 12, 308. [CrossRef] [PubMed]

22. Shin, H.C.; Kim, S.H.; Park, Y.; Lee, B.H.; Hwang, H.J. Effects of 12-week Oral Supplementation of Ecklonia cava Polyphenols on Anthropometric and Blood Lipid Parameters in Overweight Korean Individuals: A Double-blind Randomized Clinical Trial. Phytother. Res. 2012, 26, 363-368. [CrossRef]

23. Brown, E.; Allsopp, P.J.; Magee, P.J.; Gill, C.I.; Nitecki, S.; Strain, C.R.; McSorley, E.M. Seaweed and human health. Nutr. Rev. 2014, 72, 205-216. [CrossRef]

24. Taichi, S.; Shinichi, K.; Atsushi, H.; Kaori, O.; Yuki, S.; Naoki, N.; Yoshikazu, N.; Yoshitaka, T.; Ichiro, T. Dietary patterns and cardiovascular disease mortality in Japan: A prospective cohort study. Int. J. Epidemiol. 2007, 3, 600-609. [CrossRef]

25. Lee, H.Y.; Won, J.C.; Kang, Y.J.; Yoon, S.H.; Choi, E.-O.; Bae, J.Y.; Sung, M.H.; Kim, H.-R.; Yang, J.H.; Oh, J.; et al. Type 2 Diabetes in Urban and Rural Districts in Korea: Factors Associated with Prevalence Difference. J. Korean Med. Sci. 2010, 25, 1777-1783. [CrossRef]

26. Shin, A.; Lim, S.-Y.; Sung, J.; Shin, H.-R.; Kim, J. Dietary Intake, Eating Habits, and Metabolic Syndrome in Korean Men. J. Am. Diet. Assoc. 2009, 109, 633-640. [CrossRef]

27. Duval, S.; Tweedie, R.L. Trim and fill: A simple funnel-plot-based method of testing and adjusting for publication bias in meta-analysis. Biomedical 2000, 56, 455-463. [CrossRef]

28. Higgins, J.P.T.; Thompson, S.G. Quantifying heterogeneity in a meta-analysis. Stat. Med. 2002, 21, 1539-1558. [CrossRef]

29. Sakai, C.; Abe, S.; Kouzuki, M.; Shimohiro, H.; Ota, Y.; Sakinada, H.; Takeuchi, T.; Okura, T.; Kasagi, T.; Hanaki, K. A Randomized Placebo-controlled Trial of an Oral Preparation of High Molecular Weight Fucoidan in Patients with Type 2 Diabetes with Evaluation of Taste Sensitivity. Yonago Acta Med. 2019, 62, 14-23. [CrossRef]

30. Sanaei, M.; Ebrahimi, M.; Banazadeh, Z.; Shafiee, G.; Khatami, F.; Ahadi, Z.; Heshmat, R. Consequences of AphanizomenonFlos-aqua e( AFA ) extract ( Stemtech TM ) on metabolic profile of patients with type 2 diabetes. J. Diabetes Metab. Disord. 2015, 14, 50. [CrossRef]

31. Sun, K.M.; Yun, K.J.; Hwan, C.W.; Sun, L.S. Effects of seaweed supplementation on blood glucose concentration, lipid profile, and antioxidant enzyme activities in patients with type 2 diabetes mellitus. Nutri. Res. Pract. 2008, 2, 62-67.

32. Lee, S.H.; Jeon, Y.J. Efficacy and safety of a dieckol-rich extract (AG-dieckol) of brown algae, Ecklonia cava, in pre-diabetic individuals: A double-blind, randomized, placebo-controlled clinical trial. Food Funct. 2015, 6, 853-858. [CrossRef]

33. Alam, A.; Quamri, S.; Fatima, S.; Roqaiya, M.; Ahmad, Z. Efficacy of Spirulina (Tahlab) in Patients of Type 2 Diabetes Mellitus (Ziabetus Shakri)—A Randomized Controlled Trial. J. Diabetes Metab. 2016, 7. [CrossRef]

34. Lee, E.H.; Park, J.-E.; Choi, Y.-J.; Huh, K.-B.; Kim, W.Y. A randomized study to establish the effects of spirulina in type 2 diabetes mellitus patients. Nutr. Res. Pract. 2008, 2, 295-300. [CrossRef]

35. Parikh, P.; Mani, U.; Iyer, U. Role of Spirulina in the Control of Glycemia and Lipidemia in Type 2 Diabetes Mellitus. J. Med. Food 2001, 4, 193-199. [CrossRef]

36. Anitha, L.; Chandralekha, K. Effect of supplementation of Spirulina on blood glucose, glycosylated hemoglobin and lipid profile of male noninsulin dependent diabetics. Asian J. Exp. Biol. Sci. 2010, 1, 36-46.

37. Sansawa, H.; Inoue, K.; Shirai, T. Effect of Chlorella Tablet Ingestion on Mild Hypercholesterolemic Patients. Nippon. Shokuhin Kagaku Kogaku Kaishi 2002, 49, 395-400. [CrossRef]

38. Mikami, N.; Hosokawa, M.; Miyashita, K.; Sohma, H.; Ito, Y.M.; Kokai, Y. Reduction of HbA1c levels by fucoxanthin-enriched akamoku oil possibly involves the thrifty allele of uncoupling protein 1 (UCP1): A randomised controlled trial in normal-weight and obese Japanese adults. J. Nutr. Sci. 2017, 6, 5. [CrossRef] 
39. Park, H.-J.; Lee, H.S. The influence of obesity on the effects of spirulina supplementation in the human metabolic response of Korean elderly. Nutr. Res. Pract. 2016, 10, 418-423. [CrossRef]

40. Kim, C.O.; Kim, Y.N.; Lee, D.-C. Effects of Gelidium elegans on Weight and Fat Mass Reduction and Obesity Biomarkers in Overweight or Obese Adults: A Randomized Double-Blinded Study. Nutrition 2019, 11, 1513. [CrossRef]

41. Yousefi, R.; Mottaghi, A.; Saidpour, A. Spirulina platensis effectively ameliorates anthropometric measurements and obesity-related metabolic disorders in obese or overweight healthy individuals: A randomized controlled trial. Complement. Ther. Med. 2018, 40, 106-112. [CrossRef]

42. Ebrahimi-Mameghani, M.; Aliashrafi, S.; Javadzadeh, Y.; AsghariJafarabadi, M. The Effect of Chlorella vulgaris Supplementation on Liver Enzymes, Serum Glucose and Lipid Profile in Patients with Non-Alcoholic Fatty Liver Disease. Health Promot. Perspect. 2014, 4, 107-115.

43. Panahi, Y.; Pishgoo, B.; Jalalian, H.; Mohammadi, E.; Taghipour, H.R.; Sahebkar, A.; Abolhasani, E. Investigation of the effects of Chlorella vulgaris as an adjunctive therapy for dyslipidemia: Results of a randomised open-label clinical trial. Nutr. Diet. 2012, 69, 13-19. [CrossRef]

44. Takeshi, O.; Kazuhiro, S.; Seiji, M. Changes in arterial stiffness and nitric oxide production with Chlorelladerived multicomponent supplementation in middle-aged and older individuals. J. Clin. Biochem. Nutr. 2015, 57, 228-232.

45. Taiki, M.; Kiyotaka, N.; Hideo, T.; Ohki, H.; Shunji, K.; Momoko, K.; Fumiko, K.; Teruo, M. Ingestion of Chlorella Reduced the Oxidation of Erythrocyte Membrane Lipids in Senior Japanese Subjects. J. Oleo Sci. 2013, 62, 873-881.

46. Kwak, J.H.; Baek, S.H.; Woo, Y.; Han, J.K.; Kim, B.G.; Kim, O.Y.; Lee, J.H. Beneficial immunostimulatory effect of short-termChlorellasupplementation: Enhancement ofNatural Killercell activity and early inflammatory response (Randomized, double-blinded, placebo-controlled trial). Nutr. J. 2012, 11, 53. [CrossRef]

47. Kim, S.; Kim, J.; Lim, Y.; Kim, Y.J.; Kim, J.Y.; Kwon, O. A dietary cholesterol challenge study to assess Chlorella supplementation in maintaining healthy lipid levels in adults: A double-blinded, randomized, placebo-Controlled study. Nutr. J. 2016, 15, 54. [CrossRef]

48. Szulinska, M.; Gibas-Dorna, M.; Miller-Kasprzak, E.; Suliburska, J.; Miczke, A.; Walczak-Gałezewska, M.; Stelmach-Mardas, M.; Walkowiak, J.; Bogdanski, P. Spirulina maxima improves insulin sensitivity, lipid profile, and total antioxidant status in obese patients with well-treated hypertension: A randomized double-blind placebo-Controlled study. Eur. Rev. Med. Pharmacol. Sci. 2017, 21, 2473-2481.

49. Zeinalian, R.; Farhangi, M.A.; Shariat, A.; Saghafi-Asl, M. The effects of Spirulina Platensis on anthropometric indices, appetite, lipid profile and serum vascular endothelial growth factor (VEGF) in obese individuals: A randomized double blinded placebo controlled trial. BMC Complement. Altern. Med. 2017, 17, 225. [CrossRef]

50. Samuels, R.; Mani, U.V.; Iyer, U.M.; Nayak, U.S. Hypocholesterolemic Effect of Spirulina in Patients with Hyperlipidemic Nephrotic Syndrome. J. Med. Food 2002, 5, 91-96. [CrossRef]

51. Ramamoorthy, A.; Premakumari, S. Effect of supplementation of spirulina on Hypercholesterolemic patients. J. Food Sci. Technol. 1996, 33, 124-128.

52. Park, H.J.; Lee, Y.J.; Ryu, H.K.; Kim, M.-H.; Chung, H.W.; Kim, W.Y. A Randomized Double-Blind, Placebo-Controlled Study to Establish the Effects of Spirulina in Elderly Koreans. Ann. Nutr. Metab. 2008, 52, 322-328. [CrossRef] [PubMed]

53. Jensen, G.S.; Drapeau, C.; Lenninger, M.; Benson, K.F. Clinical Safety of a High Dose of Phycocyanin-Enriched Aqueous Extract from Arthrospira (Spirulina) platensis: Results from a Randomized, Double-Blind, Placebo-Controlled Study with a Focus on Anticoagulant Activity and Platelet Activation. J. Med. Food 2016, 19, 645-653. [CrossRef]

54. Corona, D.M.H.; Martínez-Abundis, E.; González-Ortiz, M. Effect of Fucoidan Administration on Insulin Secretion and Insulin Resistance in Overweight or Obese Adults. J. Med. Food 2014, 17, 830-832. [CrossRef]

55. Mizote, A.; Yamada, M.; Yoshizane, C.; Arai, N.; Maruta, K.; Arai, S.; Endo, S.; Ogawa, R.; Mitsuzumi, H.; Ariyasu, T.; et al. Daily Intake of Trehalose Is Effective in the Prevention of Lifestyle-Related Diseases in Individuals with Risk Factors for Metabolic Syndrome. J. Nutr. Sci. Vitaminol. 2016, 62, 380-387. [CrossRef]

56. Huang, H.; Liao, D.; Pu, R.; Cui, Y. Quantifying the effects of spirulina supplementation on plasma lipid and glucose concentrations, body weight, and blood pressure. Diabetes Metab. Syndr. Obes. Targets Ther. 2018, 11, 729-742. [CrossRef] 
57. Serban, M.-C.; Sahebkar, A.; Dragan, S.; Andrica, F.; Urosniu, S.; Banach, M. A systematic review and meta-analysis of the impact of spirulina supplementation on plasma lipid concentrations. Atherosclerosis 2015, 241, e191. [CrossRef]

58. Marathe, P.H.; Gao, H.X.; Close, K.L. American Diabetes Association Standards of Medical Care in Diabetes 2017. J. Diabetes 2017, 9, 320-324. [CrossRef]

59. Hammoud, T.; Tanguay, J.-F.; Bourassa, M.G. Management of coronary artery disease: Therapeutic options in patients with diabetes. J. Am. Coll. Cardiol. 2000, 36, 355-365. [CrossRef]

60. Shafrir, E. Development and consequences of insulin resistance: Lessons from animals with hyperinsulinaemia. Diabetes Metab. 1996, 22, 122-131.

61. Schröder, H. Protective mechanisms of the Mediterranean diet in obesity and type 2 diabetes. J. Nutr. Biochem. 2007, 18, 149-160. [CrossRef]

62. Murata, M.; Ishihara, K.; Saito, H. Hepatic fatty acid oxidation enzyme activities are stimulated in rats fed the brown seaweed, Undaria pinnatifida (wakame). J. Nutr. 1999, 129, 146-151. [CrossRef]

63. Maeda, H.; Hosokawa, M.; Sashima, T.; Murakami-Funayama, K.; Miyashita, K. Anti-obesity and anti-diabetic effects of fucoxanthin on diet-induced obesity conditions in a murine model. Mol. Med. Rep. 2009, 2, 897-902. [CrossRef]

64. Nagaoka, S.; Shimizu, K.; Kaneko, H.; Shibayama, F.; Morikawa, K.; Kanamaru, Y.; Otsuka, A.; Hirahashi, T.; Kato, T. A Novel Protein C-Phycocyanin Plays a Crucial Role in the Hypocholesterolemic Action of Spirulina platensis Concentrate in Rats. J. Nutr. 2005, 135, 2425-2430. [CrossRef]

65. Kulshreshtha, A.; Jarouliya, U.; Bhadauriya, P.; Prasad, G.; Bisen, P. Spirulina in Health Care Management. Curr. Pharm. Biotechnol. 2008, 9, 400-405. [CrossRef]

66. Upasani, C.D.; Balaraman, R. Protective effect of Spirulina on lead induced deleterious changes in the lipid peroxidation and endogenous antioxidants in rats. Phytother. Res. 2003, 17, 330-334. [CrossRef]

67. Miczke, A.; Szulińska, M.; Hansdorfer-Korzon, R.; Kręgielska-Narożna, M.; Suliburska, J.; Walkowiak, J.; Skrypnik, D. Effects of spirulina consumption on body weight, blood pressure, and endothelial function in overweight hypertensive Caucasians: A double-blind, placebo-controlled, randomized trial. Eur. Rev. Med. Pharmacol. Sci. 2016, 20, 150-156.

68. Ku, C.S.; Yang, Y.; Park, Y.; Lee, J. Health Benefits of Blue-Green Algae: Prevention of Cardiovascular Disease and Nonalcoholic Fatty Liver Disease. J. Med. Food 2013, 16, 103-111. [CrossRef]

69. Turner, R.C.; Millns, H.; Neil, H.A.W.; Stratton, I.; E Manley, S.; Matthews, D.R.; Holman, R.R. Risk factors for coronary artery disease in non-insulin dependent diabetes mellitus: United Kingdom prospective diabetes study (UKPDS: 23). BMJ 1998, 316, 823-828. [CrossRef]

70. Ford, E.S.; Mokdad, A.H. Fruit and Vegetable Consumption and Diabetes Mellitus Incidence among U.S. Adults. Prev. Med. 2001, 32, 33-39. [CrossRef]

71. Qureshi, A.A.; Sami, S.A.; Khan, F.A. Effects of stabilized rice bran, its soluble and fiber fractions on blood glucose levels and serum lipid parameters in humans with diabetes mellitus Types I and II. J. Nutr. Biochem. 2002, 13, 175-187. [CrossRef]

72. Jurkovic, N.; Kolb, N.; Colic, I. Nutritive value of marine algaeLaminaria japonica and Undaria pinnatifida. Food/Nahrung 1995, 39, 63-66. [CrossRef] [PubMed]

73. Urbano, M.G.; Goñi, I. Bioavailability of nutrients in rats fed on edible seaweeds, Nori (Porphyra tenera) and Wakame (Undaria pinnatifida), as a source of dietary fibre. Food Chem. 2002, 76, 281-286. [CrossRef]

74. Lahaye, M. Marine algae as sources of fibres: Determination of soluble and insoluble dietary fibre contents in some 'sea vegetables'. J. Sci. Food Agric. 1991, 54, 587-594. [CrossRef]

75. Wong, K.H.; Sam, S.; Cheung, P.; Ang, P. Changes in lipid profiles of rats fed with seaweed-based diets. Nutr. Res. 1999, 19, 1519-1527. [CrossRef]

76. Mani, U.V.; Desai, S.; Iyer, U. Studies on the Long-Term Effect of Spirulina Supplementation on Serum Lipid Profile and Glycated Proteins in NIDDM Patients. J. Nutraceuticals Funct. Med. Foods 2000, 2, 25-32. [CrossRef]

77. A Westphal, S.; Gannon, M.C.; Nuttall, F.Q. Metabolic response to glucose ingested with various amounts of protein. Am. J. Clin. Nutr. 1990, 52, 267-272. [CrossRef]

(C) 2020 by the authors. Licensee MDPI, Basel, Switzerland. This article is an open access article distributed under the terms and conditions of the Creative Commons Attribution (CC BY) license (http://creativecommons.org/licenses/by/4.0/). 